NBER WORKING PAPER SERIES

\title{
DO ACQUIRERS WITH MORE UNCERTAIN GROWTH PROSPECTS GAIN LESS FROM ACQUISITIONS?
}

\author{
Sara B. Moeller \\ Frederik P. Schlingemann \\ René M. Stulz \\ Working Paper 10773 \\ http://www.nber.org/papers/w10773 \\ NATIONAL BUREAU OF ECONOMIC RESEARCH \\ 1050 Massachusetts Avenue \\ Cambridge, MA 02138 \\ September 2004
}

We gratefully acknowledge the contributions of I/B/E/S International Inc. and First Call for providing forecast data. We thank Kose John, Carrie Pan, and Greg Sommers for helpful comments and suggestions. The views expressed herein are those of the author(s) and not necessarily those of the National Bureau of Economic Research.

(C2004 by Sara B. Moeller, Frederik P. Schlingemann, and René M. Stulz. All rights reserved. Short sections of text, not to exceed two paragraphs, may be quoted without explicit permission provided that full credit, including () notice, is given to the source. 
Do Acquirers With More Uncertain Growth Prospects Gain Less From Acquisitions?

Sara B. Moeller, Frederik P. Schlingemann, and René M. Stulz

NBER Working Paper No. 10773

September 2004

JEL No. G31, G32, G34

\begin{abstract}
$\underline{\text { ABSTRACT }}$
Behavioral finance models imply that an increase in shares outstanding leads to a lower stock price for firms with greater diversity in opinion among investors. Information asymmetry models imply that share issues by firms with greater information asymmetries are accompanied by larger share price decreases. Valuation models predict a negative relation between uncertainty resolution and share prices. Acquisition announcements are used to investigate these predictions. We find acquirer abnormal returns for acquisitions of public firms paid for with equity (but not for acquisitions of private firms paid for with equity) are lower for firms with higher dispersion of analyst forecasts, larger change in dispersion of analyst forecasts, and higher idiosyncratic volatility. The opposite result holds for acquisitions of public firms paid for with cash for idiosyncratic volatility. We show that this evidence can best be explained by models that emphasize information asymmetries, but the behavioral models and valuation models explain part of the evidence.
\end{abstract}

Sara B. Moeller

Cox School of Business

Southern Methodist University

Dallas, TX 75275

smoeller@mail.cox.smu.edu

Frederik P. Schlingemann

Katz Graduate School of Business

University of Pittsburgh

Pittsburgh, PA 15260

schlinge@katz.pitt.edu

René M. Stulz

Department of Finance

Fisher College of Business

The Ohio State University

Columbus, OH 43210

and NBER

stulz@cob.osu.edu 


\section{Introduction}

Firms with more expected growth uncertainty are likely to have lower announcement returns for some types of acquisitions for at least three important reasons. First, in behavioral finance, growth uncertainty leads to diversity of opinion and a downward-sloping demand curve for common stock, causing poor returns on equity-financed acquisitions of public firms because they increase their supply of shares. Second, in rational expectations models, growth uncertainty can be due to information asymmetry between corporate insiders and outside shareholders which leads to adverse announcement returns for acquisitions paid for with equity because management is more likely to use equity if it is overvalued. Conversely, announcement returns are more favorable for acquisitions paid for with cash because the use of cash signals that equity is not overvalued. Third, an acquisition can reduce uncertainty about a firm's future growth prospects. Such uncertainty resolution is associated with a decrease in firm value in some valuation models.

In this paper, we investigate the relation between growth uncertainty and acquirer returns. A forward-looking measure of growth uncertainty is the dispersion of analyst forecasts of long-term earnings growth. We find that acquisition returns for acquisitions of public firms paid for with equity are negatively related to the dispersion of analyst forecasts. This result is especially strong for high valuation firms. Among firms in the top tercile of market-to-book, the difference in abnormal returns between firms in the bottom tercile of forecast dispersion and the top tercile of forecast dispersion is $6 \%$. This relation does not exist for other types of acquisitions. More generally, we find that acquirer returns in acquisitions of public firms paid for with equity are strongly negatively correlated with a proxy for growth uncertainty. In contrast, the abnormal returns for other types of acquisitions, especially acquisitions of public firms paid for with cash, are positively related to some of these variables.

With greater growth uncertainty, it is easier for investors to disagree because the data speak less clearly. Miller (1977) and Chen, Hong, and Stein (2002), among others, show that diversity of opinion about a firm's growth prospects leads to a downward demand curve for its stock. With 
these models, the slope of the demand curve increases with diversity of opinion among investors. As the supply of shares increases, it has to be absorbed by investors who have a lower opinion of the stock. With greater diversity of opinion, there are fewer investors with valuations close to the market price before the increase in the supply of shares so the price has to fall sufficiently so investors with lower valuations will buy the new shares. ${ }^{1}$

Hong, Scheinkman, and Xiong (2004) provide additional testable predictions. In their model, investors are overconfident and have heterogeneous beliefs. Because they have a valuable option to sell the shares later to more optimistic investors, investors pay more than they believe the shares are worth. When the supply of shares increases, however, the most optimistic investors may not be able to absorb the supply increase, which wipes out the speculative froth in the stock price. The extent to which the bubble component of the stock price decreases in magnitude depends on the standard deviation of the investors' beliefs. Their model therefore predicts a negative relation between the announcement return and investor heterogeneity. It also predicts the drop in value of the stock to be higher when the bubble component in the stock price is higher, so that highly valued bidders with high diversity of opinion are expected to experience worse returns. Further, given a firm's valuation and diversity of opinion, the drop in value should be proportionately greater for firms that issue more equity. Finally, to the extent that acquisitions of private firms paid for with equity do not increase the bidder's float, diversity of opinion models predict that there should be no relation between abnormal returns and diversity of opinion for such acquisitions.

\footnotetext{
${ }^{1}$ In a paper completed at the same time as this paper, Baker, Coval, and Stein (2004) investigate the relation between merger returns and diversity of opinion using a sample of stock swaps. They posit that, in a stock merger, some target shareholders are "sleepy" in that they will hold on to the equity received as consideration even though they would not have bought that equity on their own. They show theoretically and empirically that mergers returns should be lower for mergers where target investors are less likely to be "sleepy." This is because target shareholders who are not "sleepy" will sell the equity they receive as consideration since they did not value the equity of the acquirer highly in the first place. Consequently, when investors hold strong opinions about the value of the acquirer, the equity received by shareholders who are not "sleepy" will have to be acquired by investors who value it less than the pre-merger acquiringfirm shareholders. They show that institutional shareholders are less likely to be "sleepy" and that merger
} 
Recent literature uses the dispersion of analyst forecasts as a measure of diversity of opinion. ${ }^{2}$ Consistent with behavioral finance models, we find that the relation between diversity of opinion and acquisition returns is limited to acquisitions of public firms paid for with equity and is strongest for highly valued firms. For the firms with the greatest diversity of opinion, the effect is dramatic: The high market-to-book bidders in the top decile of diversity of opinion have average abnormal returns of $-8.3 \%$. We show that diversity of opinion is irrelevant for private firm acquisitions as well as for public acquisitions paid for with cash.

Greater uncertainty can simply reflect the existence of information asymmetries. A more traditional explanation for the negative announcement returns of acquisitions of public firms paid for with equity, put forward by Travlos (1987) and inspired by Myers and Majluf (1984), is that the announcement signals to the market that bidder management does not believe equity is undervalued. To the extent that firms with high diversity of opinion are firms where information asymmetries are significant, the information asymmetry explanation does not seem distinguishable from the diversity of opinion explanation using acquisitions of public firms paid for with equity only. Dierkens (1991) explores the relation between abnormal returns for equity issues and proxies for information asymmetries. Some of her proxies, especially the idiosyncratic volatility of the stock before the announcement, are more robustly related to announcement returns than dispersion of analyst forecasts. We find that the abnormal return for equity offers falls as idiosyncratic volatility increases, but the opposite takes place for cash offers. The evidence on cash offers cannot be explained by diversity of opinion models, but is consistent with information asymmetry models. With high volatility, there is much uncertainty about the true value of the firm. When management uses cash to finance an offer, the market infers that equity is worth more than its market value, which is good news and leads to higher abnormal returns. With acquisitions of private firms paid for with equity, we expect the willingness of the seller to

returns fall as the interaction of a diversity of opinion proxy and institutional ownership increases. Their diversity of opinion proxies are one-year earnings forecast analyst dispersion and idiosyncratic risk.

${ }^{2}$ See, for instance, Diether et al. (2002), Diether (2004), and Scherbina (2003). 
receive equity to be better news for firms with greater information asymmetries since the seller can receive information directly from the acquirer hence providing a certification benefit. We find that the abnormal returns for acquisitions of private firms are positively related to idiosyncratic volatility, but the coefficient is not significant.

Krasker (1986) extends the Myers and Majluf (1984) model to show that there is a negative relation between the post-issue price and the size of the equity issue when management can choose the size of the issue. Krasker's model therefore implies empirically a negative relation between abnormal returns and the size of an acquisition. The same prediction follows from the diversity of opinion models. We find support for that prediction. The information asymmetry models could also help us understand why diversity of opinion is more important for high marketto-book firms. Firms with a high Tobin's $q$, proxied by the market-to-book ratio, are more likely to have a larger fraction of their value derived from growth opportunities and other assets associated with greater information asymmetries. If so, then firms with high dispersion of analyst forecasts and high Tobin's $q$ are likely to exhibit the greatest degree of information asymmetry.

Pástor and Veronesi (2004) show that uncertainty about a firm's long-term growth prospects increases firm value in an efficient market. Their model offers an alternative explanation for the negative relation between bidder abnormal returns and the dispersion of analyst forecasts that we investigate extensively. Their reasoning is straightforward when a firm's value is estimated using Gordon's growth model. In that model, firm value is a convex function of the firm's expected growth rate. Consequently, an increase in uncertainty about the firm's expected growth rate leads to a higher firm value because of Jensen's inequality. Johnson (2004) reaches the same conclusion. With the Pástor and Veronesi (2004) and Johnson (2004) models, a merger would be associated with a drop in firm value if it lowers uncertainty about a firm's future expected growth. To the extent that highly valued firms are firms with high growth uncertainty that are more sensitive to resolution of uncertainty, we expect an acquisition announcement that reduces growth uncertainty should be accompanied by a drop in firm value unless there is an 
accompanying synergy gain large enough to offset the resolution of uncertainty effect. We find a strong negative relation between the resolution of uncertainty and merger returns for acquisitions of public firms paid for with equity. This relation is so strong that it tends to overwhelm the relation between abnormal returns and the level of dispersion of analyst forecasts. One might be tempted to conclude therefore that the relation between bidder returns and the dispersion of analyst forecasts can be explained by the role of growth uncertainty in valuation. However, contrary to the models, we do not observe the same relation for private firm acquisitions and for acquisitions paid for with cash. Alternatively, the relation we document might be due to reversecausation: analysts observe poor announcement returns and draw similar conclusions from them, so that the dispersion of analyst forecasts is reduced.

The three main reasons why expected growth uncertainty is related to acquisition abnormal returns have different implications for agency costs and market efficiency. With the behavioral finance hypothesis as well as with the information asymmetry hypothesis, the market overvalues the acquirer's equity immediately before the announcement. However, in the former case it is because investors are overoptimistic while in the latter case it is because investors do not have information that management has. With the valuation model of Pástor and Veronesi (2004), it could also be that the market overvalues the firm immediately before the acquisition if, at that time, managers already know they will make the acquisition and know its implications for the firm's expected growth. Irrespective of the reason why expected growth uncertainty matters, the value of the acquirer changes when the announcement is made for reasons that have nothing to do with whether the acquisition has synergy effects. Importantly, divergence between a firm's market value and its value as known to the managers can lead these managers to make poor acquisitions to try to prop up firm value as emphasized by Jensen (2004). Consequently, the negative relation between our measures of growth uncertainty and abnormal returns is partly due to firms making poorer acquisitions. It is important to note, however, that our results hold when 
we control for firm valuation measures such as market-to-book, which presumably would account for at least part of that effect.

All the models we investigate predict that the relation between bidder returns and dispersion of analyst forecasts should be permanent. While Mitchell et al. (2004) show that there is a temporary price pressure effect associated with equity offers for public companies, Diether (2004) demonstrates that higher dispersion of opinion is associated with lower long-term returns following corporate actions such as equity issues and mergers paid for with equity. We show that the worse returns of mergers undertaken by firms with greater diversity of opinion are not reversed over the next twenty days. It turns out, instead, that the abnormal return differential we document is amplified over the twenty days that follow the merger announcement. In particular, we find that the acquirers with the highest valuations and highest dispersion of opinion have an abnormal return that is $5.9 \%$ lower than the abnormal return of acquirers with the highest valuations and lowest dispersion of opinion.

A concern with a result like ours is that dispersion of analyst forecasts could proxy for other variables that affect abnormal returns. In our regressions, we control for known variables related to bidder returns. We also investigate how variables related to analyst dispersion affect our results. In a recent paper, Scherbina (2003) finds evidence that firms that have experienced a worsening of their prospects over the past year are more likely to have high analyst forecasts dispersion. We estimate regressions where we control for changes in forecasts as well, including the change in forecasts over the previous year. None of our results are affected by taking into account forecast changes in our regressions.

The paper proceeds as follows. In Section 2, we describe our sample of acquisitions. In Section 3, we introduce our measures of analyst dispersion. In Section 4, we show how abnormal returns are related to analyst dispersion for different types of acquisitions. In Section 5, we examine more directly predictions from the behavioral literature. In Section 6, we use proxies for information asymmetries used by Dierkens (1991) to more directly investigate the implications of 
information asymmetry models. We examine the resolution of uncertainty hypothesis in Section 7. In Section 8, we show that the poor returns for bidders with high dispersion of analyst forecasts are permanent and not explained by past changes in analyst forecasts. We conclude in Section 9 .

\section{The acquisition sample}

To analyze the relation between the dispersion of analyst forecasts and the acquirer's acquisition announcement abnormal return, we start from a sample of successful and unsuccessful acquisition announcements constructed from the Securities Data Company's (SDC) U.S. Mergers and Acquisitions Database. We require that the deal value corresponds to at least $1 \%$ of the market value of the assets of the acquirer (defined as the book value of assets minus the book value of equity plus the market value of equity). In addition, the sample of acquisitions meets the following criteria:

1. The acquisition is announced in the period from 1980 to 2002 and neither the acquirer nor target has another merger announcement in the 3 day window;

2. The acquirer controls less than $50 \%$ of the shares of the target at the announcement date and obtains $100 \%$ of the target shares if the target is a public or private firm;

3. The deal value is equal to or greater than $\$ 1$ million;

4. The target is a U.S. public firm or a U.S. private firm;

5. Data on the acquirer is available from CRSP and COMPUSTAT;

6. The deal is classified by SDC as either successful, unconditional, or withdrawn;

7. If successful the deal is completed in less than one thousand days.

We find 11,393 acquisition announcements that meet these criteria. Next, we require the acquiring firm to have a forecast for long-term growth of earnings per share and to be followed by at least three analysts, measured in the month preceding the acquisition. The requirement that three analysts follow the firm is due to the fact that we compute the standard deviation of analyst 
forecasts. To compute a standard deviation, we need at least two observations, but we focus on cases where we have at least three forecasts to avoid putting too much weight on outliers. Though we believe that this measure is more reliable, our results also hold if we require only two analyst forecasts to compute our measure of dispersion. Our information on analyst forecasts is obtained from the Summary History File of the Institutional Brokers Estimate System (I/B/E/S) database. This requirement dramatically reduces the size of our sample since it forces us to discard 7,974 announcements to end with a sample of 3,419 announcements.

Table 1 provides and compares information on acquirer and deal characteristics for the full sample of acquisitions and the subset with analyst data. Panel A of Table 1 shows that imposing the requirement of analyst forecasts availability increases sharply the mean and median transaction value for the acquisitions considered. Further, the acquisitions become less important relative to the market value of equity of the acquirer or the market value of the assets (defined as book value of assets plus market value of equity minus book value of equity). Acquisitions for which we have analyst data are less likely to be financed with cash and more likely to be financed with equity. They are also more likely to be acquisitions of public firms than of private firms and less likely to be conglomerate acquisitions. It follows from this that the sample of acquisitions with analyst forecasts is not a representative sample of all acquisitions. Hong, Lim, and Stein (2000), LaPorta (1996), and Diether, Malloy, and Scherbina (2002), among others, already noted that the intersection of CRSP, COMPUSTAT, and I/B/E/S is severely skewed towards larger companies. This explains that acquirers with analyst forecasts are larger acquirers. This is confirmed in Panel B. We see that, whether using book value of assets, market value of assets or market value of equity, acquirers with analyst forecasts are much larger than acquirers without such forecasts. There is also evidence that the acquirers with forecasts are valued more than those without as can be seen from the higher Tobin's $q$ and lower book-to-market ratio for acquirers with forecasts. We use market-to-book, computed as total assets minus the book value of common equity plus the market value of common equity divided by total assets, as a proxy for 
Tobin's $q$. The acquirers with forecasts have also more cash and less leverage. They do not, however, have significantly higher operating income.

We use the Center for Research in Securities Prices (CRSP) database to collect daily return data for our sample of acquirers and data for the equally-weighted index. We estimate the acquirer abnormal returns, $C A R_{(-1,+1)}$, associated with the three-day window surrounding the acquisition announcements in our sample for each year using standard event study methods (see e.g., Brown and Warner (1985)). We compute market model abnormal returns using the CRSP equally weighted index and the parameters for the market model are estimated over the $(-205$, -6) day interval. The $p$-values are obtained using the time-series and cross-sectional variation of abnormal returns. ${ }^{3}$

In Panel $\mathrm{C}$ of Table 1, we report the mean and median announcement abnormal returns. We show that the mean announcement abnormal return of firms with analyst data is roughly 100 basis points less than the mean announcement abnormal return of firms in the unrestricted sample. The differences in acquirer size between the two samples as well as the greater prevalence of equity offers in the restricted sample help explain this difference in abnormal returns. The difference in abnormal returns is significant for the medians for public firm acquisitions, but there is no difference between the medians for private firm acquisitions.

Another selection bias induced by restricting the sample to only acquirers with at least three analyst forecasts is that the fraction of acquirers with analyst forecasts increases over time. Consequently, the percentage of acquisitions made by firms followed by at least three analysts is higher in recent years, so the proportion of acquisitions included in our sample is higher on average during the last five years of the sample period. The restricted sample has $21.51 \%$ of the

\footnotetext{
${ }^{3}$ We also calculate abnormal returns using the value-weighted CRSP market return in the estimation of the market model and using net-of-market returns. Our results are not sensitive to these alternate definitions of abnormal returns.
} 
unrestricted acquisitions from 1980 through 1990, 31.65\% from 1991 through 2002, and 38.24\% from 1998 through 2002. The latest merger wave is therefore overrepresented in the sample.

\section{Measures of dispersion of analyst forecasts}

The earnings and long-term earnings growth forecasts are collected from I/B/E/S. The month of the acquisition is defined as the $\mathrm{I} / \mathrm{B} / \mathrm{E} / \mathrm{S}$ statistical period in which the announcement occurs unless that announcement is within 6 business days of the end of the period. In that case, the next month is considered the month of the acquisition so the $\mathrm{I} / \mathrm{B} / \mathrm{E} / \mathrm{S}$ information has time to incorporate the announcement (see Pound (1988)).

Our empirical work focuses on the long-term earnings growth forecast which $\mathrm{I} / \mathrm{B} / \mathrm{E} / \mathrm{S}$ defines as a three to five year forecast of the expected annual increase in operating earnings over the company's next full business cycle. The primary reason we choose the long-term growth forecast over other time horizons, i.e., quarterly and yearly, is that it features prominently in valuation models. This long-term forecast also has several other advantages. First, quarterly or yearly earnings forecasts are affected by how close a firm is to the end of a fiscal quarter or year and by how important earnings guidance is for a firm. These considerations are less likely to influence the long-term growth forecast. Second, quarterly or yearly forecasts typically have to be normalized to be made comparable across firms. A firm could have a higher forecast than another firm simply because it has fewer shares. Many papers normalize the forecasts by the firm's share price (e.g., Pound, 1988; Thomas, 2002). Since the long-term forecast is an expected growth rate, it is directly comparable across firms.

The main variable of interest in our analysis is the dispersion of analyst forecasts before the acquisition announcement. The difficulty with this variable is that the dispersion of analyst forecasts is somewhat higher when a firm has few - but more than one - analysts. Therefore, we also use a different measure of dispersion of analyst forecasts. For each number of analyst forecasts, we rank the standard deviation of forecasts and we call high analyst dispersion firms 
those who rank in the top decile of dispersion of analyst forecasts among firms with the same number of analyst forecasts.

Table 2 provides information on our analyst measures. All of our data come from the Summary File. Diether et al. (2002) report a rounding bias due to stock splits, but when they correct for it, they find that it does not affect their results. Moreover, the rounding bias does not affect the long-term growth forecast. We show in Panel A of Table 2 the average and median of respectively the standard deviation and the median of the long-term growth forecast, the one-year earnings forecast, and the quarterly earnings forecast for various samples. The first column is the whole $\mathrm{I} / \mathrm{B} / \mathrm{E} / \mathrm{S}$ sample for which a long-term growth forecast is available and there are at least three analysts. The second column in the table is the sample of acquisitions.

Comparing the acquirers to all $\mathrm{I} / \mathrm{B} / \mathrm{E} / \mathrm{S}$ firms using a Wilcoxon median test, we first see that the acquirers have higher long-term growth prospects and more dispersion in long-term growth forecasts. The greater long-term growth prospects is consistent with the evidence presented in the literature that firms make acquisitions after having outperformed the market. ${ }^{4}$ It is better to focus on medians for earnings since averages can be influenced by large outliers. Using a sign-rank test for differences, we find that acquirers' earnings forecasts are less disperse and slightly lower for the yearly variable, but the opposite holds for the quarterly variable.

The third column in Table 2 is the full time-series median of the sample of acquiring firms excluding the forecasts from one month prior to and one month after the merger announcement. We find that the overall median of dispersion and levels of long-term growth across all acquirers measured during the month prior to the acquisition are, respectively, lower and the same than they are for all other months. However, when compared for each firm on a pairwise-basis, we find that the median value of the long-term growth dispersion is higher during the month prior to the acquisition than during the median of the other months. There are no economically meaningful differences in terms of the other forecasts. 
Panel B shows changes in all these measures from one month before the acquisition to the month after the announcement. The mean changes are generally not significant and all the median changes are zero when rounded to three digits. For comparison, we compute changes over the same length of time for the whole $\mathrm{I} / \mathrm{B} / \mathrm{E} / \mathrm{S}$ sample. The dispersion of forecasts has a significant positive mean and the level of forecasts has a significant negative mean. Similar results hold for yearly earnings, but not for quarterly earnings. Again, all the medians are zero when rounded to three digits.

\section{Dispersion of analyst forecasts and abnormal returns}

To investigate whether acquisition abnormal returns are related to the dispersion of analyst forecasts, we divide all acquirers into terciles of dispersion of analyst forecasts. Table 3 reports the abnormal returns for all acquirers and for each type of acquisition. To ensure that our results are not due to outliers, abnormal returns are winsorized at $1 \%$ and $99 \%$ in constructing Table 3 . We find similar results when we include all observations. The first row in the table shows the abnormal returns for all transactions. The abnormal returns are generally close to zero, but surprisingly, given the discussion in the introduction, high dispersion firms have significantly higher abnormal returns than low dispersion firms. The explanation for this can be inferred from the subsequent rows: Relatively more acquisitions made by high dispersion firms are private-firm acquisitions. We already know that private-firm acquisitions have positive abnormal returns (see e.g., Chang, 1998; Fuller, Netter, and Stegemoller, 2002). The second row shows the results for acquisitions of public firms paid for with equity. Not surprisingly, the abnormal returns are negative. We see there, however, a highly significant difference between high dispersion firms and low dispersion firms. The difference of $-2.154 \%$ is not only statistically significant, but economically as well. For instance, while the literature has made much of the difference between equity acquisitions and cash acquisitions of public targets, that difference is of a similar

\footnotetext{
${ }^{4}$ See Asquith, et al. (1983).
} 
magnitude in our sample (-2.371\%). If we use our decile measure of dispersion (not reported), the difference between the high dispersion firms and the others becomes $-3.589 \%$. The third row shows the result for acquisitions of private firms paid for with equity and the fourth row for acquisitions of public firms paid for with cash. In these rows, dispersion of analyst forecasts is not associated with significant variation in abnormal returns.

There is a strong relation between analyst forecasts dispersion and abnormal returns for acquisitions of public firms paid for with equity. This relation raises the question of whether analyst forecasts dispersion proxies for variables that are known to predict bidder returns. To examine this issue, we estimate regressions of bidder returns on variables that the literature has typically used to predict returns and add our analyst forecasts dispersion measures.

In Regression (1) of Table 4, the bidder abnormal return for acquisitions of public firms paid for with equity is regressed on the measure of analyst forecasts dispersion and a constant. We find that the measure of analyst forecasts dispersion has a negative significant coefficient. The coefficient is -0.0028 . The standard deviation of the measure of dispersion of analyst forecasts is 5.64. Consequently, a change of two standard deviations of the measure of dispersion of analyst forecasts corresponds to a change in abnormal return of 3.2\%. The regression confirms the results reported in Table 3 showing that dispersion of analyst forecasts has an economically and statistically significant relation with abnormal returns for public acquisitions financed with equity.

In Regression (2), we add the variables that other papers often use to explain acquirer abnormal returns. Note first that the measure of dispersion of analyst forecasts is still significant. The coefficient is now slightly smaller in absolute value. It follows that dispersion of analyst forecasts does not proxy for other variables used to explain acquirer abnormal returns. Maloney, McCormick, and Mitchell (1993) show that firms with higher leverage make better acquisitions. We therefore use the market value of leverage as a control variable. This variable is significantly positive. Second, we use a proxy for Tobin's q. Earlier research (Lang, Stulz, and Walkling, 
1989; Servaes, 1991) finds higher abnormal returns for firms with a higher Tobin's $q$. Research with samples constructed from SDC that include the latest merger wave do not find this result (Moeller, Schlingemann, and Stulz, forthcoming; Dong, Hirshleifer, Richardson, and Teoh, 2002). The coefficient on Tobin's $q$ is negative but not significant. It is also economically trivial. There is evidence that conglomerate acquisitions have worse returns (see Morck, Shleifer, and Vishny, 1990). A dummy variable that takes a value of one if the acquirer and the acquired firm are in the same industry is not significant. We find no evidence that the abnormal return is significantly different for competed offers or for offers to which the target reacts with hostility. Following Asquith, Bruner, and Mullins (1983), bidder return regressions generally control for the size of the target relative to the size of the acquirer for acquisitions of public firms, to adjust for the impact of an acquisition on the equity market capitalization of the acquiring firm. We find a strong negative effect of relative size on acquisition returns. The operating cash flow normalized by the book value of assets has a positive yet insignificant coefficient. Moeller, Schlingemann, and Stulz (2004) show that acquisitions by small firms have higher abnormal returns. They use a dummy variable for small firms that take a value of one for firms with a capitalization below the $25^{\text {th }}$ percentile of the NYSE in the year of the acquisition. This variable has a highly significant positive coefficient. Finally, we control for the liquidity of the market for corporate assets in the industry of the target using the liquidity index constructed in Schlingemann, Walkling, and Stulz (2002). We find that the coefficient on the liquidity index is positive and significant.

In regression (3) and (4), we replicate, respectively, regressions (1) and (2) for acquisitions of private firms paid for with equity. For this subsample there are no hostile deals or tender offers, so these dummy variables are excluded from the model. As predicted by diversity of opinion models, the coefficient on the dispersion of analyst forecasts variable is not significantly different from zero. It is not just an issue of statistical significance, however. The coefficient in regressions (3) is only one-quarter of the value of the coefficient in regression (1). It is interesting to note that 
the relative size variable has a positive insignificant slope for private-firm acquisitions in contrast to a negative significant slope for public-firm acquisitions.

Analysts produce forecasts for the next quarter as well as for the next year. We investigate whether the results we have shown so far hold for these alternate measures of dispersion of analyst forecasts. These measures in many ways are less compelling because firm value is much more sensitive to the forecast of long-run growth than it is to forecasts of next quarter's or next year's earnings. We follow Pound (1988) and Thomas (2002) and normalize the earnings forecast by the stock price. Regressions (5) and (6) show the results when we add the same set of control variables as in model (2). We find a strong negative coefficient for these measures of dispersion. In regression (7), we put all three measures of dispersion in the regression. Multicollinearity renders all coefficients insignificant. The results using the quarterly and yearly forecasts seem sensitive to how the forecasts are normalized. If we normalize instead by the mean forecast, the coefficients on the dispersion measures are negative but not significant. Though we do not reproduce the regressions, the quarterly and yearly earnings forecast dispersions have positive insignificant coefficients for private-firm acquisitions.

The last two regressions in the table use our alternate measure of diversity of opinion, which is a dummy variable for firms in the top decile of analyst forecasts dispersion given their number of analyst forecasts. We find that this variable has a negative significant coefficient for acquisitions of public firms paid for with equity and a positive insignificant coefficient for acquisitions of private firms paid for with equity.

To check that the role of dispersion of analyst forecasts is significantly different between acquisitions of public firms and acquisitions of private firms paid for with equity, we also estimate (not reported) regressions using all acquisitions paid for with equity but allowing the slope on the dispersion of analyst forecasts to differ for acquisitions of private firms. In these regressions, we find that the coefficient on dispersion of analyst forecasts for private firm acquisitions is significantly higher than the coefficient for public firm acquisitions. 


\section{Abnormal returns, valuation, and diversity of opinion}

One reason that growth uncertainty matters is that it fosters diversity of opinion. The result that abnormal returns for acquisitions of public firms paid for with equity are negatively related to dispersion of analyst forecasts is consistent with the predictions of models that emphasize the importance of diversity of opinion. The diversity of opinion models also predict that abnormal returns for acquisitions that do not increase the float should be unrelated to diversity of opinion. Acquisitions paid for with cash do not increase the float, so the lack of significance of the proxies for diversity of opinion measures is supportive of diversity of opinion models. Acquisitions of private firms paid for with equity increase the float only if the shares paid to the seller are not held by the seller as long-term investments.

To check whether the result that there is no relation between abnormal returns for acquisition of private firms paid for with equity and dispersion of analyst forecasts is supportive of diversity of opinion models, we explore whether the shares available for trading increase with such acquisitions. We cannot measure the number of share available for trading directly, but we can conduct an indirect test. If public firm acquisitions paid for with equity increase the float more than private firm acquisitions paid for with equity, it should be that the percentage change in the number of shares traded from before the announcement of the acquisition to after its completion is significantly higher for public than for private deals.

To investigate this, we collect data on bidder volume from CRSP for two windows of 50 days. The first window ends 25 days before the announcement and the second window starts 25 days after completion. The median percentage change in volume for public acquisitions paid for with equity is $58.33 \%$; in contrast, it is $29.36 \%$ for acquisitions of private firms paid for with equity and $13.07 \%$ for acquisitions of public firms paid for with cash. The above median changes are significantly different from zero and from each other. With our assumption that the float increases only with acquisitions of public firms paid for with equity, the size of the acquisition for an acquisition of a private firm with equity or of a public firm with cash should have no relation 
with the volume percentage change. To investigate this, we regress the volume percentage change on a constant, a dummy for private equity acquisitions (PrivEq), a dummy for public firm acquisitions paid for with cash (PubCash), a dummy for private firm acquisitions paid for with cash (PrivCash), the ratio of deal value to bidder market capitalization (TVMVE), interactions of the dummy variables with the ratio of deal value bidder market capitalization, and year dummies. The estimated regression is:

Volume percentage change $=0.5690+0.0341 \times$ PrivEq $-0.2901 \times$ PubCash $-0.1729 \times$ PrivCash $+0.9102 \times$ TVMVE $-0.8107 \times[$ PrivEq $\times$ TVMVE $]-0.9216 \times[$ PubCash $\times$ TVMVE $]-0.6917$ $\times[$ PrivCash $\times$ TVMVE]

All coefficients are significant at the $1 \%$ level. The regression is estimated on 1,763 observations and has an adjusted R-squared of 0.066. The impact of TVMVE on the volume percentage change is not significantly different from zero for acquisitions of private firms paid for with equity or acquisitions of public firms paid for with cash. It is therefore reasonable to believe that acquisitions of private firms paid for equity have a negligible effect on the bidder's float, so our result that there is no relation between abnormal returns for such acquisitions and dispersion of analyst forecasts is consistent with the diversity of opinion models. Further, the result of Table 4 that the abnormal return for public-firm acquisitions paid for with equity falls as the ratio of deal value to market value of the acquirer increases, but the abnormal return for private-firm acquisitions does not, is also consistent with diversity of opinion models.

Growth uncertainty should matter more for firms with higher valuations because the value of such firms is more sensitive to the expected growth rate. In Hong, Scheinkman, and Xiong (2004), diversity of opinion matters for firms that are overvalued because of the resale option embedded in the stock, i.e., the option that the stock may be sold to more optimistic investors later. Hence, if Tobin's $q$ is correlated with overvaluation, their model predicts that diversity of 
opinion is more important for firms with a high Tobin's $q$. We therefore investigate whether the relation between dispersion of analyst forecasts and abnormal return depends on a firm's valuation.

In Table 5, we divide all firms in the sample according to the acquirer's market-to-book ratio, our proxy for Tobin's $q$, and to its dispersion of analyst forecasts. This also allows us to test the hypothesis that the relation between diversity of opinion and bidder return for acquisitions of public firms financed with equity should be stronger for bidders with higher valuations. Similar to the procedure in Table 3, we winsorize abnormal returns at $1 \%$ and $99 \%$ in constructing Table 5 to ensure that our results are not due to outliers. Winsorizing does not affect our conclusions. The results in Panel A of Table 5 are consistent with the hypothesis that diversity of opinion and bidder return for acquisitions of public firms financed with equity are more strongly related for bidders with higher valuations. For firms with low and medium market-to-book ratios, there is no significant difference in abnormal returns between acquirers with high and low dispersion of analyst forecasts. In contrast, when we turn to firms with high valuations, the difference between acquirers with high and low dispersion of analyst forecasts is $-2.797 \%$ with a $p$-value of 0.049 . It is interesting to note that valuation seems to matter only for the firms with high dispersion of analyst forecasts since the difference in abnormal returns between high Tobin's $q$ and low Tobin's $q$ firms is not significant unless a firm has a high dispersion of analyst forecasts. However, the 127 firms that are in the highest Tobin's $q$ tercile and in the highest analyst forecasts dispersion tercile have an average abnormal return of $-5.81 \%$.

The diversity of opinion models predict that diversity of opinion should not be relevant for acquisitions of private firms paid for with equity or for acquisitions of public firms paid for with cash, irrespective of the valuation of the bidder. Panel B of Table 5 reports results for acquisitions of private firms paid for with equity when we use dispersion of analyst forecasts as a proxy for diversity of opinion. We find that acquisitions by firms with higher dispersion of analyst forecasts have insignificantly higher abnormal returns. The results in Panel $\mathrm{C}$ of Table 5 show that high 
dispersion of analyst forecasts bidders with low valuations have higher abnormal returns than low dispersion of analyst forecasts bidders with similar valuations for public-firm acquisitions paid for with cash. The $p$-value is 0.081 . This result, albeit weak, indicates that the evidence cannot be explained by diversity of opinion models alone.

As discussed earlier, we also use a different proxy for opinion diversity. We split the sample depending on whether a firm, among all firms with the same number of analysts, is in the top decile of analyst forecasts dispersion. While not reported, our results hold with this approach when we consider the whole sample of acquisitions of public firms paid for with equity. High dispersion acquirers with this measure have predominantly high valuations. Consequently, the results for medium and low valuation firms are not meaningful since there are only 10 firms with low valuation and high dispersion of analyst forecasts and 13 firms with medium valuation and high dispersion of analyst forecasts. Strikingly, the 51 firms with high valuation and high dispersion of analyst forecasts have a mean abnormal return of $-8.30 \%$ when using the decile dummy.

Hong, Scheinkman, and Xiong (2004) predict that the abnormal returns for float increases should be worse for high valuation firms with investors with highly heterogeneous beliefs. To examine this prediction, we divide the high valuation/high dispersion of analyst forecasts firms into three groups based on the ratio of deal value to bidder market capitalization. The results are reported in Panel D of Table 5 and are striking. The group of 42 bidders where the ratio is the highest has a mean abnormal return of $-9.27 \%$. In contrast, the group of 43 bidders where the ratio is lowest has a mean abnormal return of $-4.25 \%$. The difference between these two groups is significant with a $p$-value of less than one percent. The 42 bidders in the middle group have an average abnormal return of $-3.95 \%$. We also estimated regressions of abnormal returns on the ratio of deal value to bidder market capitalization for the firms with high valuation and high dispersion of analyst forecasts. For public-firm acquisitions, the coefficient on the ratio is -0.019 with a $p$-value of 0.036 . In contrast, for private-firm acquisitions, the coefficient is 0.018 with a 
$p$-value of 0.221 (not reported). This evidence is supportive of the Hong, Scheinkman, and Xiong (2004) model.

\section{Information asymmetry or diversity of opinion?}

We find that abnormal returns for acquisitions of public firms paid for with equity but not for other types of acquisitions are worse for firms with greater dispersion of analyst forecasts, that the relation between abnormal returns and dispersion of analyst forecast is magnified for firms with high valuations, and that, among firms with high valuations and high dispersion of analyst forecasts, the worst returns are by firms that make the largest acquisitions. Since the acquisitions of public firms paid for with equity are, among all acquisition types, those that increase the float the most, these results are supportive of models that emphasize the role of diversity of opinion if dispersion of analyst forecasts proxies well for diversity of opinion. We would expect dispersion of analyst forecasts to be high when information asymmetries between managers and outside shareholders are also high. Models of information asymmetries can explain all of our results since it would not be unreasonable to presume that dispersion of analyst forecasts proxies well for the extent of information asymmetries. To see this, note that we know from Myers and Majluf (1984) that equity issues are associated with a drop in stock prices and from Krasker (1986) that the magnitude of the drop increases with the size of the issue. Further, it is often argued that high Tobin's $q$ firms have higher information asymmetries because more of their value comes from intangible assets. The information asymmetry hypothesis would predict that greater information asymmetry does not make abnormal returns worse for cash acquisitions or for acquisitions of 
private firms paid for with equity (since in that case the buying firm can provide information to the seller it could not provide to investors in general). ${ }^{5}$

To understand better the extent to which our results can be explained by asymmetric information models, we investigate the relation between abnormal returns and proxies for information asymmetries used in the literature. Dierkens (1991) uses four variables to describe the information environment of a firm in a study of the announcement effect of seasoned primary equity issues. These variables are the standard deviation of the earnings announcement abnormal return, the firm's idiosyncratic volatility, the firm's turnover, and the number public announcements of the firm. She has no prediction on the coefficient of turnover, but she predicts a negative coefficient on idiosyncratic volatility. Regression (1) of Table 6 adds idiosyncratic volatility to regression (2) of Table 4 . We measure idiosyncratic volatility in a similar way as in Dierkens (1991), namely the standard deviation of the market-adjusted residuals of the daily stock returns measured during the period starting from 205 days to 6 days prior to the acquisition announcement. We find that idiosyncratic volatility is highly significant with a negative coefficient. When idiosyncratic volatility is added to the regression, dispersion of analyst forecasts is no longer significant. The coefficient of correlation between idiosyncratic volatility and dispersion of analyst forecasts is 0.42 . We estimate the idiosyncratic volatility that is orthogonal to the dispersion of analyst forecasts. When we use this decomposition in regression (2), we find that the coefficient on dispersion of analyst forecasts is still insignificant, but its value is similar to its value without idiosyncratic volatility and the $p$-value is 0.13 . We then use our alternative measure of high dispersion of analyst forecasts, the top decile dummy of analyst

\footnotetext{
${ }^{5}$ Note that there is a literature that draws attention to information asymmetries about the target as well and makes the choice of means of payment dependent on these asymmetries. An example and empirical test of such a model is Eckbo, Giammarino, and Heinkel (1990). Their empirical work is not supportive of the model. Other models with information asymmetries emphasize that the acquisition signals that a firm has run out of internal investment opportunities, see Braguinsky and Jovanovic (2004) and McCardle and Viswanathan (1994). These models are not helpful here because we are focusing on the role of growth uncertainty across acquisitions with significantly negative abnormal returns (public acquisitions paid for with equity) as well as acquisitions with significantly positive abnormal returns (private acquisitions paid for with equity).
} 
forecasts, in regression (3). That measure has a significant coefficient. In regression (4), we add the standard deviation of earnings announcements and turnover to regression (1). The earnings announcement standard deviation is measured as the standard deviation of all 3-day cumulative abnormal returns around earnings announcements from $\mathrm{I} / \mathrm{B} / \mathrm{E} / \mathrm{S}$ using the market model over the 5-year period preceding the acquisition announcement. Turnover is defined as the median of daily volume divided by shares outstanding from day $(-205,-6)$ relative to the acquisition announcement day. We still find that idiosyncratic volatility has a negative significant coefficient. Neither the standard deviation of earnings announcements nor the turnover measure is significant. If we remove the dispersion of analyst forecasts from regression (1) and replace it with turnover, turnover has a significant negative coefficient.

To save space, we do not reproduce the regressions for acquisitions of private firms paid for with equity. In these regressions, neither the dispersion of analyst forecasts nor idiosyncratic volatility has a significant coefficient. The coefficient on dispersion of analyst forecasts is negative but close to zero; the coefficient on idiosyncratic volatility is positive. When we estimate regression (5) for these acquisitions, the standard deviations of earnings announcements has a positive significant coefficient.

The models that focus on diversity of opinion predict that the announcement return of an acquisition paid for with cash should not be related to a proxy for diversity of opinion since no new equity is issued. In contrast, models based on information asymmetries imply that the announcement return on acquisitions paid for with cash should increase with variables that measure information asymmetry. Not issuing equity when financing an acquisition must be interpreted as positive news about the value of equity and it must be more positive news when there is greater uncertainty about the true value of the firm. Regressions (5) through (8) in Table 6 replicate regressions (1) through (4) for acquisitions of public firms paid for with cash. Idiosyncratic volatility has a significant positive coefficient in regressions (5) through (7) and a pvalue of 0.105 in regression (8). In regression (6), the dispersion of analyst forecasts has a 
positive significant coefficient as well, and in regression (7) our alternate measure of high dispersion of analyst forecasts has a significant positive coefficient. When we have only one proxy for growth uncertainty in a regression (not reported), the absolute earnings announcement abnormal return has a positive significant coefficient for acquisitions of public firms paid for with cash.

The Myers and Majluf (1984) model implies that an equity issue conveys information about the value of assets in place. Jain (1992) tests that implication of the model by regressing changes in analyst forecasts around the time of an equity issuance on the issue abnormal return. We find some supportive, albeit weak evidence in Table 2 where the median change in acquirer yearly and quarterly earnings forecasts is lower around acquisitions than at other times. In contrast, the difference of medians for long-term earnings growth is positive. This evidence is for all acquisitions, but the Myers-Majluf (1984) prediction is about firms issuing equity, and thus applies to equity-financed acquisitions only. Though we do not report the results in a table, we compare changes in forecasts for the three types of acquisitions we focus on. Using median changes, we find acquisitions of private firms paid for with equity have the highest change and public acquisitions paid for with cash have the lowest change, with the acquisitions of public firms paid for with equity in the middle. The only significant difference using the long-term earnings growth forecasts is between acquisitions of public firms paid for with equity and acquisitions of public firms paid for with cash. Using yearly earnings forecasts normalized by the stock price, the change is significantly higher for private firm acquisitions paid for with equity than for public firm acquisitions paid for with cash, but the $p$-value for the comparison between public firm acquisitions paid for with equity and public firm acquisitions paid for with cash is not significant. In sum, changes in analyst forecasts are not supportive of the Myers-Majluf (1984) prediction since with that prediction the change should be lowest for acquisitions of public firms paid for with equity. 
The significant coefficients on some of the variables used in Dierkens (1991) in the regressions for cash acquisitions of public firms and equity acquisitions of private firms cannot be explained by diversity of opinion models and are direct evidence of a distinct role for information asymmetries, so that these variables are supportive of the Myers-Majluf (1984) model in contrast to the analyst forecast changes. The results for acquisitions of public firms paid for with equity can be explained by diversity of opinion as well as information asymmetries unless one has strong priors that idiosyncratic volatility is only a proxy for asymmetric information.

\section{Changes in forecast dispersion and bidder abnormal returns}

The asymmetric information models imply that investors learn from corporate actions, so information asymmetry should fall following a merger announcement. To the extent that investors learn in models with heterogeneous beliefs, they should also learn from merger announcements, so that heterogeneous beliefs models predict in that case that the abnormal return is higher for firms where the dispersion of analyst forecasts falls more. Table 2 shows that the mean, but not the median, change in dispersion of analyst forecasts from before the announcement of an acquisition to after the announcement is significantly negative. The valuation model of Pástor and Veronesi (2004) predicts a positive relation between a firm value and uncertainty about its long-run expected growth. We proxy for long-run expected growth with the dispersion of analyst long-term growth forecasts. Our measure of the change in dispersion of analyst forecasts is the difference between the dispersion of analyst forecasts in month $t+1$ and month $t-1$, where month $t$ denotes the acquisition announcement month. The change in dispersion has a correlation of -0.2 with the level of the dispersion of analyst forecasts. Consequently, firms with high dispersion of analyst forecasts are expected to see a drop in their dispersion of analyst forecasts.

We first compare the abnormal returns for bidders where the change in dispersion is negative with the abnormal return for bidders where the change is positive, ignoring the firms where the 
change is zero. The bidders with a decrease in dispersion of analyst forecasts have a worse abnormal return by $1.26 \%$ on average for acquisitions of public firms paid for with equity. After the beginning of 1998 the difference is $3 \%$ which is especially large. In contrast, the difference for acquisitions of private firms has the opposite sign and is $-1.22 \%$.

In Table 7, we first show regressions where the dependent variable is the bidder abnormal return and the explanatory variables are, respectively, the dispersion of analyst forecasts, the change in analyst forecasts dispersion, and the change in the median analyst forecasts for acquisitions of public firms in regression (1) and acquisitions of private firms using equity financing in regression (2). We find that the changes in the dispersion of analyst forecasts and changes in the median analyst forecast are not significant in regressions (1) and (2). However, in regressions (3) and (4) we add our control variables from Section 5 and find that the change in dispersion has a positive significant coefficient for the sample of public-firm acquisitions. Hence, bidders whose long-term growth dispersion falls have worse announcement returns, while the level of the dispersion of analyst forecasts is no longer significant. The coefficient on the change in the dispersion of analyst forecasts is consistent with the prediction from the model of Pástor and Veronesi (2004). In models (5), (6), (7) and (8) we repeat the first four regressions using our measure of dispersion based on the top decile of dispersion of analyst forecasts among all acquirers with the same number of analysts. That measure remains significant, irrespective of the addition of the control variables, for acquisitions of public firms when the change in dispersion is added. The change in dispersion is not significant for acquisitions of private firms in any of the specifications. Also, for private-firm acquisitions, neither the dispersion of analyst forecasts nor the change in the median forecast is significant. We also estimate, but do not report, regressions for cash acquisitions and find that the analyst forecast variables are not significant.

The result that the change in dispersion is significant for acquisitions of public firms paid for with equity, but not for other acquisitions, does not fit well with model of Pástor and Veronesi (2004). That model predicts that if an acquisition reduces uncertainty about future expected 
growth it should be associated with a drop in the stock price, everything else equal, regardless of how it is financed. One possible explanation is that a firm that issues equity to pay for a public firm acquisition conveys different information than if it pays for an acquisition with cash or if it pays for a private-firm acquisition with equity. For instance, Myers and Majluf (1984) predict that issuing equity to unrelated investors conveys bad news about firm value. Hence, analysts might infer that the firm has worse growth prospects if it finances a public-firm acquisition with equity, but not for other types of acquisitions. Another possible explanation is simply that poor announcement returns dampen the optimism of the most optimistic analysts. In that case, causality would run from the abnormal return to the dispersion of analyst forecasts.

\section{Is the abnormal return differential associated with diversity of opinion permanent and can it be explained by past changes in analyst forecasts?}

An additional prediction coming out of the models that argue growth uncertainty should be related to abnormal returns of acquisition announcements is that the relation should be permanent. If the effect we document is temporary, acquisitions of public firms by firms with high valuations and high dispersion of analyst forecasts should have a higher abnormal return after the acquisition announcement than similar acquisitions by firms with high valuations and low dispersion of analyst forecasts. To examine this, we estimate the abnormal returns for the 20 trading days after the announcement period for the subsamples used in Panels A and B of Table 5. These estimates are provided in Table 8. In Panel A, we find that the post-announcement abnormal return for the sample of acquirers of public firms that use equity and have high dispersion of analyst forecasts is worse than for those with low dispersion of analyst forecasts. The difference in abnormal returns is $-3.75 \%$ with a $p$-value of 0.005 . When sorting our sample by Tobin's q terciles and dispersion of analyst forecasts terciles, we find that the 20-day abnormal returns have large standard errors so they are typically not significant for most sorts. Nonetheless, there is a significant difference in abnormal returns between high and low dispersion acquirers for high valuation firms that is 
economically large, $-5.91 \%$, and significant. This difference explains the post-announcement abnormal return difference for the whole sample. In any case, there is no evidence of reversals for firms with a high dispersion of analyst forecast.

In Panel $\mathrm{B}$ of Table 8, we investigate the post-announcement abnormal returns for the acquisitions of private firms. We do not find significant differences between high and low dispersion acquirers. For high valuation firms, the difference in post-announcement abnormal returns between high and low diversity acquirers is $-0.21 \%$ with a $p$-value of 0.945 . Therefore, as for announcement returns, differences in dispersion of analyst forecasts do not appear to matter for firms that make acquisitions of private firms paid for with equity.

Another approach to evaluate whether the effect we document is transitory is to estimate a regression of post-announcement returns on announcement returns, dispersion of analyst forecasts, and dispersion of analyst forecasts interacted with announcement returns. Reversal of the announcement return would imply a negative coefficient on the announcement return. Reversal of the effect we document requires a negative coefficient on the interaction of dispersion of analyst forecasts and the announcement return. When we estimate this regression (not reported) for offers to acquire public firms financed with equity, the coefficient on the announcement return is 0.022 with a $p$-value of 0.064 , the coefficient on the interaction is 0.0164 with a $p$-value of 0.399 , and the coefficient on dispersion of analyst forecasts is -0.004 with a $p$-value of 0.168 . The coefficient on the interaction is negative, but not significant. Surprisingly, though, the coefficient on the interaction is negative and significant for private offers.

Scherbina (2003) provides evidence that analyst forecasts dispersion is related to the prior performance of the firm. This raises the concern that our measure of forecast dispersion could proxy for changes in the level of forecasts or for the level of forecasts. To examine this possibility, we estimate but do not report regressions where we add changes in the long-term forecast as well as the level of the forecast. We first add the past-year change in the long-term 
growth forecast to regression (2) from Table 4, which includes the forecast dispersion and prior control variables. The forecast dispersion remains significant with no change in the coefficient while the past-year change is not significant. We then add to that regression the dispersion of quarterly and yearly forecasts. We find that adding these forecasts does not change the coefficient on the dispersion of long-term forecasts. Finally, we add to that regression the quarterly earnings surprise since Scherbina concludes that analysts are too optimistic when dispersion is high. The quarterly earnings surprise is calculated as the actual quarterly earnings minus the most recent median (mean) analyst forecast if the announcement occurred during the period starting one month before the announcement and ending one month after the announcement. If no announcement occurred in that period, the earnings surprise is zero. Adding the quarterly earnings surprise does not change our results. We repeat these regressions for private firm acquisitions paid for with equity. The coefficient on the dispersion of long-term forecasts is insignificant in each model for private acquisitions.

\section{Conclusion}

Growth uncertainty can be related to acquisition abnormal returns for at least three reasons: (1) greater investor heterogeneity is associated with a downward-sloping demand curve for stock, so the stock price has to fall to absorb a greater supply of shares with acquisitions of public firms financed with equity; (2) growth uncertainty is associated with information asymmetries so the choice of means of payment in acquisitions is a signal of the true value of the firm's equity; and (3) firm value is increasing in growth uncertainty and falls with resolution of uncertainty, so acquisitions that decrease growth uncertainty but do not have large synergy gains result in a decrease in firm value. In this paper, we show that firms with greater growth uncertainty have worse announcements return for acquisitions of public firms paid for with equity and, for at least some measures of growth uncertainty, better announcement returns for acquisitions of public 
firms paid for with cash. For acquisitions of private firms paid for with equity, there is no significant relation between growth uncertainty and abnormal returns.

The resolution of uncertainty hypothesis predicts that any acquisition that reduces uncertainty should be associated with a drop in firm value for growth firms, regardless of whether the acquired firm is public or private and irrespective of how the acquisition is financed. The evidence does not support the hypothesis in this form. The diversity of opinion models imply that diversity of opinion should not be related to the announcement return when no equity is issued. The results for cash acquisitions of public firms do not seem consistent with this prediction. The asymmetric information models predict that the announcement return for cash offers should increase with measures of information asymmetry. The evidence is supportive of this prediction when the measure of information asymmetry is the acquirer's idiosyncratic volatility. Only information asymmetry models seem readily capable of explaining this result. The evidence therefore supports an important role for information asymmetries, but the diversity of opinion models and the resolution of uncertainty model explain some of the results we find as well. 


\section{References}

Asquith, P., Bruner, R., Mullins, D., 1983. The gains to bidding firms from merger. Journal of Financial Economics 11, 121-139.

Baker, M., J. Coval, and J.C. Stein, 2004, Corporate financing decisions when investors take the path of least resistance, unpublished paper, Harvard Economics Department, Cambridge, MA.

Brown, Stephen J., Warner, J.B., 1985. Using daily stock returns, the case of event studies. Journal of Financial Economics 14, 3-31.

Chang, S., 1998. Takeovers of privately held targets, method of payment, and bidder returns. Journal of Finance 52, 773-784.

Chen, J.S.,, Hong, H.G., Stein, J., 2002. Breadth of Ownership and Stock Returns. Journal of Financial Economics 66, 171-205.

Dierkens, N., 1991. Information asymmetry and equity issues. Journal of Financial and Quantitative Analysis 26, 181-200.

Diether, K., 2004. Long-run event performance and opinion divergence. Working paper, The Ohio State University.

Diether, K.B., Malloy, C.J., Scherbina A., 2002. Differences of opinion and the cross section of stock returns. Journal of Finance 57, 2213-2141.

Dong, M., D. Hirshleifer, S. Richardson, Teoh, S.H., 2003. Does investor misvaluation drive the takeover market? unpublished working paper, The Ohio State University, Columbus, OH.

Eckbo, B. E., Giammarino, R.M., Heinkel, R.L., 1990. Asymmetric information and the medium of exchange in takeovers: Theory and tests. Review of Financial Studies 3, 651-676.

Fama, E.F., French, K.R., 1993. Common risk-factors in the returns on stocks and bonds. Journal of Financial Economics 33, 3-56.

Fuller, K., J. Netter, Stegemoller, M., 2002. What do returns to acquiring firms tell us? Evidence from firms that make many acquisitions. Journal of Finance 57, 1763-1794.

Hong, H.G., Scheinkman, J.A., Xiong, W., 2004. Asset float and speculative bubbles. unpublished working paper, Princeton University, Princeton, NJ.

Hong, H., T. Lim, Stein, J.C., 2000. Bad news travels slowly: Size, analyst coverage, and the profitability of momentum strategies. Journal of Finance 55, 265-295.

Jain, P., 1992. Equity issues and changes in expectations of earnings by financial analysts. Review of Financial Studies 5, 669-683.

Jensen, M.C., 2004. Agency costs of overvalued equity. Harvard NOM Working Paper No. 0426; ECGI - Finance Working Paper No. 39/2004, Harvard University, Cambridge, MA. 
Johnson, T., 2004. Forecast dispersion and the cross-section of returns. Journal of Finance, forthcoming.

Jovanovic, B., Braguinsky, S., 2004. Bidder discounts and target premia in takeovers. American Economic Review 94, 46-56.

Krasker, W. S., 1986. Stock price movements in response to stock issues under asymmetric information. Journal of Finance 41, 93-106.

Lang, L. H. P., Stulz, R. M., Walkling, R. A., 1989. Managerial performance, Tobin's Q, and the gains from successful tender offers. Journal of Financial Economics 24, 137-154.

LaPorta, R., 1996. Expectations and the Cross-Section of Stock Returns. Journal of Finance $51(5)$.

McCardle, K.F., Viswanathan, S., 1994. The direct entry versus takeover decision and stock price performance around takeovers. Journal of Business 67, 1-43.

Maloney, M.T., R.E. McCormick, Mitchell, M.L., 1993. Managerial decision making and capital structure. Journal of Business 66, 189-217.

Miller, E. M., 1977. Risk, uncertainty, and divergence of opinion. Journal of Finance 32, 11511168.

Mitchell, M., Pulvino T., Stafford, E., 2004. Price pressure around mergers. Journal of Finance, 59(1), 31-63.

Moeller, S.B., Schlingemann, F.P., Stulz, R.M., 2004. Firm size and the gains from acquisitions. Journal of Financial Economics 73, 201-228.

Moeller, S.B., Schlingemann, F.P., Stulz, R.M., forthcoming, Wealth destruction on a massive scale: A study of acquiring firm returns in the merger wave of the late 1990's. Journal of Finance.

Morck, R., Shleifer, A., Vishny, R.W., 1990. Do managerial objectives drive bad acquisitions? Journal of Finance 45, 31-48.

Myers, S. C., Majluf, N.S., 1984. Corporate financing and investment decisions when firms have information that investors do not have. Journal of Financial Economics 13, 187-221.

Pástor, L., Veronesi, P., 2004. Was there a Nasdaq bubble in the late 1990s? CRSP Working Paper No. 557, University of Chicago, Chicago, IL.

Pound, J., 1988. The information effects of takeover bids and resistance. Journal of Financial Economics 22, 207-227.

Scherbina, A., 2003. Analyst disagreement, forecast bias and stock returns. unpublished working paper, Harvard University, Cambridge MA.

Schlingemann, F.P., Stulz, R.M., Walkling, R.A., 2002. Divestitures and the liquidity of the market for corporate assets. Journal of Financial Economics 64, 117-144. 
Servaes, H., 1991. Tobin's q, agency costs, and corporate control: An empirical analysis of firm specific parameters. Journal of Finance 46, 409-419.

Thomas, S., 2002. Firm diversification and asymmetric information: Evidence from analysts' forecasts and earnings announcements. Journal of Financial Economics 64, 373-396.

Travlos, N.G., 1987. Corporate takeover bids, methods of payment, and bidding firms' stock returns. Journal of Finance 42, 943-963. 
Table 1

Sample Summary Statistics

The sample of successful and unsuccessful acquisitions by publicly listed U.S. acquirers is from SDC Merger and Acquisition Database for the period 1980-2002 for all deals involving U.S. private or public targets. The sample is presented unrestricted (all) and restricted to deals with coverage by three or more analysts and available data on long-term earnings growth forecasts (with analyst data), where $n$ lists the number of observations. The transaction value is from SDC and represents the total value of consideration paid by the acquirer, excluding fees and expenses. The market value of equity (MVE) is the shares outstanding times the stock price at the fiscal year end prior to the announcement and the market value of assets (MVA) is the book value of assets minus the book value of equity plus MVE. Days to completion measures the number of days between the announcement and effective date (for successful deals). Competed, hostile, tender offer, and cash and equity in consideration are from SDC. Same industry deals involve targets with the same 2-digit SIC code as that of the bidder. The liquidity index for the target is calculated as the value of corporate control transactions for each year and 2-digit SIC code divided by the total book value of assets of firms in the 2-digit SIC code for that year. Cash includes cash and marketable securities and is normalized by the book value of assets. Leverage is measured as the ratio of long-term and short-term debt, and the market (book) value of assets. Tobin's $q$ is defined as the book value of assets minus the book value of equity plus the MVE, divided by the book value of assets. Book-to-Market is defined as in Fama and French (1993). Operating cash flow is defined as sales minus the cost of goods sold, sales and general administration and working capital change, normalized by MVA. Small dummy is equal to one if the acquirer has a MVE equal or less than the MVE of the smallest quartile of NYSE firms in each year. The $\mathrm{CAR}_{(-1,+1)}$ denotes the 3-day cumulative abnormal return (in percent) measured using market model residuals. Respectively, ${ }^{\mathrm{a}}{ }^{\mathrm{b}}$, and ${ }^{\mathrm{c}}$ denote statistical significance at the $1 \%, 5 \%$, and 10\% level based on $t$-tests (means) and Wilcoxon-tests (medians) of the difference between the two samples.

\begin{tabular}{|c|c|c|c|c|}
\hline \multirow[t]{2}{*}{ Panel A: Deal Characteristics } & \multicolumn{2}{|c|}{ All $(n=11,393)$} & \multicolumn{2}{|c|}{ With analyst data $(n=3,419)$} \\
\hline & mean & Median & mean & median \\
\hline Transaction Value (TV) & 394.01 & 29.27 & $1021.98^{\mathrm{a}}$ & $112.00^{\mathrm{a}}$ \\
\hline TV / Market Value of Assets (MVA) & 0.2749 & 0.0779 & $0.1661^{\mathrm{a}}$ & $0.0612^{\mathrm{a}}$ \\
\hline TV / Market Value of Equity (MVE) & 0.5416 & 0.1535 & $0.2891^{\mathrm{b}}$ & $0.1063^{\mathrm{a}}$ \\
\hline Competed $\times 100 \%$ & 2.95 & & $3.77^{\mathrm{b}}$ & \\
\hline Days to Completion & 83 & 55 & $88^{\mathrm{b}}$ & $67^{\mathrm{a}}$ \\
\hline Percent Cash in Consideration $\times 100 \%$ & 44.90 & 33.07 & $38.51^{\mathrm{a}}$ & $0.00^{\mathrm{a}}$ \\
\hline Percent Equity in Consideration $\times 100 \%$ & 41.89 & 11.95 & $49.83^{\mathrm{a}}$ & $50.00^{\mathrm{a}}$ \\
\hline Pure Cash in Consideration $\times 100 \%$ & 30.22 & & $24.31^{\mathrm{a}}$ & \\
\hline Pure Equity in Consideration $\times 100 \%$ & 31.87 & & $38.90^{\mathrm{a}}$ & \\
\hline Hostile $\times 100 \%$ & 1.85 & & 2.16 & \\
\hline Tender offer $\times 100 \%$ & 5.88 & & $8.86^{\mathrm{a}}$ & \\
\hline Same Industry $\times 100 \%$ & 31.44 & & $35.70^{\mathrm{a}}$ & \\
\hline Public Target $\times 100 \%$ & 34.17 & & $47.09^{\mathrm{a}}$ & \\
\hline Private Target $\times 100 \%$ & 65.83 & & $52.91^{\mathrm{a}}$ & \\
\hline Liquidity Index $\times 100 \%$ & 18.41 & 9.06 & 19.25 & $10.49^{\mathrm{a}}$ \\
\hline \multicolumn{5}{|l|}{ Panel B: Acquirer Characteristics } \\
\hline & mean & median & mean & median \\
\hline Cash / Book Value of Assets (BVA) & 0.1742 & 0.0806 & $0.1825^{b}$ & $0.0869^{b}$ \\
\hline Book Value Assets (BVA) & 2172.43 & 214.63 & $5373.07^{\mathrm{a}}$ & $704.45^{\mathrm{a}}$ \\
\hline Market Value Assets (MVA) & 3374.22 & 394.70 & $8682.03^{\mathrm{a}}$ & $1621.12^{\mathrm{a}}$ \\
\hline Market Value Equity (MVE) & 1685.64 & 208.67 & $4456.55^{\mathrm{a}}$ & $986.21^{\mathrm{a}}$ \\
\hline Leverage (MVA) & 0.2966 & 0.2533 & $0.2472^{\mathrm{a}}$ & $0.1953^{\mathrm{a}}$ \\
\hline Leverage (BVA) & 0.4569 & 0.4349 & $0.4220^{\mathrm{a}}$ & $0.4092^{\mathrm{a}}$ \\
\hline Tobin's Q & 2.3947 & 1.5282 & $3.0438^{\mathrm{a}}$ & $1.8817^{\mathrm{a}}$ \\
\hline Book-to-Market & 0.5594 & 0.4535 & $0.4330^{\mathrm{a}}$ & $0.3520^{\mathrm{a}}$ \\
\hline Operating Cash Flow (MVA) & 0.1785 & 0.0891 & 0.3198 & 0.0902 \\
\hline Small dummy & 0.5171 & & $0.1565^{\mathrm{a}}$ & \\
\hline
\end{tabular}


Table 1. (Continued)

Panel C: Abnormal returns

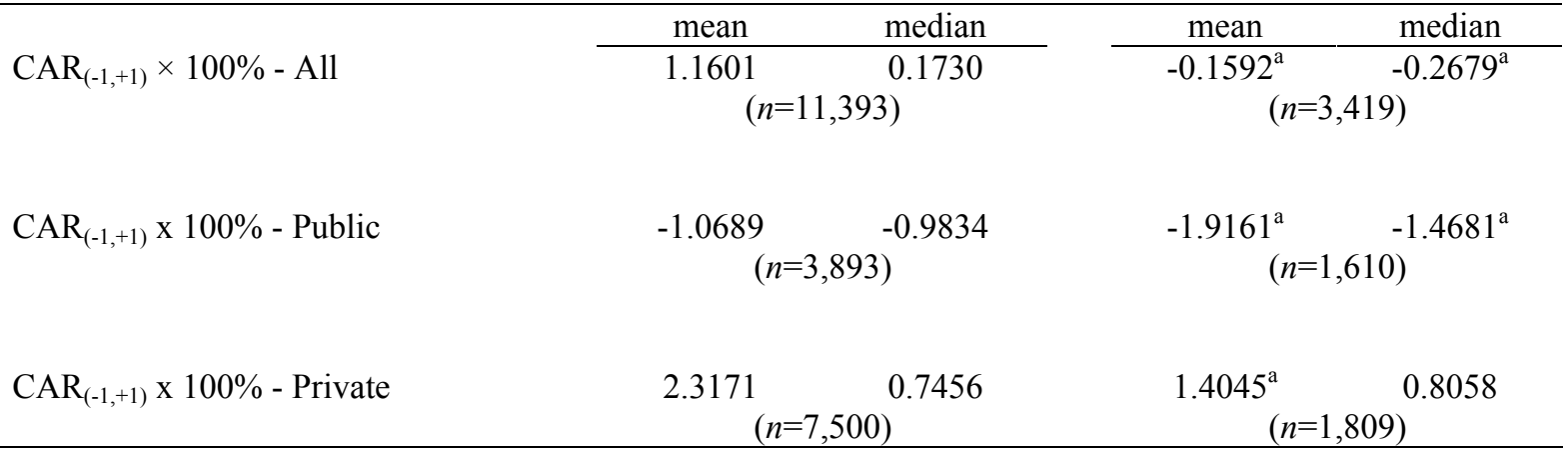


Table 2

I/B/E/S Earnings Forecast Summary Statistics

The sample of successful and unsuccessful acquisitions by publicly listed U.S. acquirers is from SDC Merger and Acquisition Database for the period 1980-2002 for all deals involving U.S. private or public targets. Column (1) contains all I/B/E/S firms with three or more analysts and available data on long-term earnings growth forecasts. The sample is presented in column (2) and consists of deals with coverage by three or more analysts and available data on long-term earnings growth forecasts. In column (3) the firm median is based on all available months on $\mathrm{I} / \mathrm{B} / \mathrm{E} / \mathrm{S}$ for the sample firms for which forecast data exists excluding the months prior, during, and after the announcement of the deal. The number of observations in each group with data on the standard deviation (std) of the long-term growth forecast is indicated with $n$. For each variable the mean and median (in brackets) is reported. In Panel A the standard deviation (std) and median (med) of the long-term earnings growth forecasts are reported in percent and the yearly (quarterly) earnings forecasts are measured in dollars normalized by the stock price (stock price/4) from I/B/E/S in the month prior to the deal. In Panel B the forecast revisions for the sample firms are the difference from the month before the announcement to the month after the announcement. The yearly (quarterly) revisions are normalized by the stock price (stock price/4). Forecast revisions for all $\mathrm{I} / \mathrm{B} / \mathrm{E} / \mathrm{S}$ firms and firm median are measured over a two-month period with overlapping windows. Respectively, ${ }^{\mathrm{a}},{ }^{\mathrm{b}}$, and ${ }^{\mathrm{c}}$ denote statistical significance at the $1 \%, 5 \%$, and $10 \%$ level based on $t$-tests (means) and Wilcoxon-tests (medians) of the unpaired differences across the groups in columns (1) - (2) and (1) - (3) and a paired $t$-test (sign-rank test) is

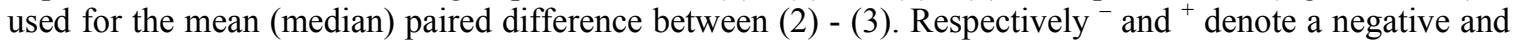
positive test-statistic in case the mean or median paired difference is rounded to zero in the table, yet significantly different from zero.

\begin{tabular}{|c|c|c|c|c|c|c|}
\hline & $\begin{array}{c}\mathrm{I} / \mathrm{B} / \mathrm{E} / \mathrm{S} \\
\text { Firms } \\
n=439,774\end{array}$ & $\begin{array}{c}\text { Sample } \\
\text { Firms } \\
n=3,419 \\
\end{array}$ & $\begin{array}{c}\text { Firm } \\
\text { Median } \\
n=3,321\end{array}$ & \multicolumn{3}{|c|}{ Differences } \\
\hline \multicolumn{7}{|l|}{ Panel A: Forecasts } \\
\hline \multirow{3}{*}{ Long-term Growth (std) } & (1) & (2) & (3) & $(1)-(2)$ & $(1)-(3)$ & $(2)-(3)$ \\
\hline & 4.328 & 4.855 & 4.519 & $-0.528^{\mathrm{a}}$ & $-0.191^{\mathrm{a}}$ & $-0.359^{\mathrm{a}}$ \\
\hline & [3.000] & [3.210] & {$[3.460]$} & {$[-0.210]^{\mathrm{a}}$} & {$[-0.460]^{\mathrm{a}}$} & {$[0.045]^{\mathrm{c}}$} \\
\hline \multirow{2}{*}{ Long-term Growth (median) } & 15.875 & 21.525 & 20.566 & $-5.650^{\mathrm{a}}$ & $-4.691^{\mathrm{a}}$ & $-0.998^{\mathrm{a}}$ \\
\hline & {$[14.000]$} & {$[20.000]$} & {$[20.000]$} & {$[-6.000]^{\mathrm{a}}$} & {$[-6.000]^{\mathrm{a}}$} & {$[0.000]^{\mathrm{a}-}$} \\
\hline \multirow[t]{2}{*}{ Yearly Earnings (std) } & 0.834 & 0.005 & 0.006 & $0.828^{\mathrm{a}}$ & $0.828^{\mathrm{a}}$ & 0.000 \\
\hline & {$[0.007]$} & {$[0.003]$} & {$[0.003]$} & {$[0.005]^{\mathrm{a}}$} & {$[0.004]^{\mathrm{a}}$} & {$[0.000]^{\mathrm{a}^{+}}$} \\
\hline \multirow{2}{*}{ Yearly Earnings (median) } & 4.036 & 0.064 & 0.064 & $3.972^{\mathrm{a}}$ & $3.972^{\mathrm{a}}$ & 0.001 \\
\hline & [0.071] & {$[0.063]$} & {$[0.067]$} & {$[0.008]^{\mathrm{a}}$} & {$[0.004]^{\mathrm{a}}$} & {$[0.004]^{\mathrm{a}}$} \\
\hline \multirow{2}{*}{ Quarterly Earnings (std) } & 0.027 & 0.005 & 0.005 & $0.022^{\mathrm{a}}$ & $0.022^{\mathrm{a}}$ & 0.000 \\
\hline & [0.001] & {$[0.002]$} & {$[0.003]$} & {$\left[-0.002^{\mathrm{a}}\right]$} & {$[-0.002]^{\mathrm{a}}$} & {$[0.000]^{\mathrm{a}+}$} \\
\hline \multirow[t]{2}{*}{ Quarterly Earnings (median) } & 0.222 & 0.051 & 0.049 & $0.170^{\mathrm{a}}$ & $0.172^{\mathrm{a}}$ & $-0.004^{b}$ \\
\hline & {$[0.007]$} & {$[0.051]$} & {$[0.055]$} & {$[-0.043]^{\mathrm{a}}$} & {$[-0.047]^{\mathrm{a}}$} & {$[0.002]^{\mathrm{a}}$} \\
\hline \multicolumn{7}{|l|}{ Panel B: Forecast revisions } \\
\hline \multirow{3}{*}{ Long-term Growth (std) } & (1) & (2) & (3) & $(1)-(2)$ & $(1)-(3)$ & $(2)-(3)$ \\
\hline & $0.027^{\mathrm{a}}$ & -0.022 & 0.015 & 0.050 & 0.012 & 0.030 \\
\hline & {$[0.000]^{\mathrm{a}}$} & {$[0.000]$} & {$[0.000]^{\mathrm{c}}$} & {$[0.000]$} & {$[0.000]$} & {$[0.000]$} \\
\hline \multirow{2}{*}{ Long-term Growth (median) } & $-0.172^{\mathrm{a}}$ & -0.028 & $-0.011^{c}$ & $-0.143^{\mathrm{b}}$ & $-0.161^{\mathrm{a}}$ & 0.020 \\
\hline & {$[0.000]^{\mathrm{a}}$} & {$[0.000]^{b}$} & {$[0.000]^{\mathrm{a}}$} & {$[0.000]^{\mathrm{a}}$} & {$[0.000]^{\mathrm{a}}$} & {$[0.000]^{c+}$} \\
\hline \multirow[t]{2}{*}{ Yearly Earnings (std) } & $0.004^{\mathrm{a}}$ & 0.001 & 0.000 & $0.004^{\mathrm{a}}$ & $0.004^{\mathrm{a}}$ & -0.001 \\
\hline & {$[0.000]^{\mathrm{a}}$} & {$[0.000]^{b}$} & {$[0.000]^{\mathrm{a}}$} & {$[0.000]^{\mathrm{b}}$} & {$[0.000]$} & {$[0.000]^{--}$} \\
\hline \multirow[t]{2}{*}{ Yearly Earnings (median) } & $-0.009^{\mathrm{a}}$ & 0.000 & $0.000^{\mathrm{a}}$ & $-0.009^{\mathrm{a}}$ & $-0.009^{\mathrm{a}}$ & 0.000 \\
\hline & {$[0.000]^{\mathrm{a}}$} & {$[0.000]^{\mathrm{a}}$} & {$[0.000]$} & {$[0.000]^{\mathrm{a}}$} & {$[0.000]^{\mathrm{a}}$} & {$[0.000]^{\mathrm{a}-}$} \\
\hline \multirow{2}{*}{ Quarterly Earnings (std) } & $0.001^{\mathrm{a}}$ & $0.000^{\bar{b}}$ & $0.000^{\mathrm{a}}$ & $0.001^{\mathrm{a}}$ & $0.001^{\mathrm{a}}$ & $0.000^{\mathrm{c}-}$ \\
\hline & {$[0.000]^{\mathrm{a}}$} & {$[0.000]^{\mathrm{a}}$} & {$[0.000]^{\mathrm{a}}$} & {$[0.000]$} & {$[0.000]$} & {$[0.000]^{\mathrm{a}-}$} \\
\hline \multirow{2}{*}{ Quarterly Earnings (median) } & $0.005^{\mathrm{a}}$ & 0.001 & $0.000^{\mathrm{a}}$ & $0.004^{\mathrm{a}}$ & $0.004^{\mathrm{a}}$ & -0.001 \\
\hline & {$[0.000]^{\mathrm{a}}$} & {$[0.000]^{\mathrm{a}}$} & {$[0.000]^{\mathrm{a}}$} & {$[0.000]^{\mathrm{a}}$} & {$[0.000]^{\mathrm{a}}$} & {$[0.000]^{--}$} \\
\hline
\end{tabular}


Table 3

Abnormal Returns by Diversity of Opinion

The sample of successful and unsuccessful acquisitions by publicly listed U.S. acquirers is from SDC Merger and Acquisition Database for the period 1980-2002 for all deals involving U.S. private or public targets. The acquirer has coverage by three or more analysts and available data on long-term earnings growth forecasts. The standard deviation (std) of the long-term earnings growth forecast is from $\mathrm{I} / \mathrm{B} / \mathrm{E} / \mathrm{S}$. Abnormal returns are defined as the 3-day cumulative abnormal return (in percent) measured using the market model residuals, where the parameters are estimated over the $(-205,-6)$ event window relative to the announcement day. Abnormal returns are winsorized at the $1 \%$ and $99 \%$ level. Cells denote respectively the mean, standard deviation (Std Dev), and number of observations $(n)$ for each group. Target status is public, private, or both (All). The form of payment is $100 \%$ equity, $100 \%$ cash, or all deals regardless of form of payment, including mixed forms of payment (All). Respectively, ${ }^{\mathrm{a}}{ }^{\text {and }}{ }^{\mathrm{b}}$ denote statistical significance at the $1 \%, 5 \%$, and $10 \%$ level based on $t$-tests of the differences of the means between the high and low groups.

\begin{tabular}{|c|c|c|c|c|c|c|c|}
\hline \multirow[b]{2}{*}{$\begin{array}{l}\text { Target } \\
\text { status }\end{array}$} & \multirow[b]{2}{*}{$\begin{array}{l}\text { Form of } \\
\text { Payment }\end{array}$} & & \multicolumn{4}{|c|}{ Long-term growth (std) } & \multirow[b]{2}{*}{$\begin{array}{c}\text { High - Low } \\
\text { p-value }\end{array}$} \\
\hline & & & Low & Mid & High & Total & \\
\hline All & All & $\begin{array}{c}\text { Mean } \\
\text { Std Dev } \\
n\end{array}$ & $\begin{array}{c}-0.659 \\
5.848 \\
991\end{array}$ & $\begin{array}{c}-0.081 \\
7.158 \\
1,206\end{array}$ & $\begin{array}{l}0.144 \\
9.042 \\
1,202\end{array}$ & $\begin{array}{c}-0.170 \\
7.559 \\
3,399\end{array}$ & $\begin{array}{c}0.803^{\mathrm{b}} \\
0.016\end{array}$ \\
\hline Public & Equity & $\begin{array}{c}\text { Mean } \\
\text { Std Dev } \\
n\end{array}$ & $\begin{array}{c}-2.149 \\
6.176 \\
263\end{array}$ & $\begin{array}{c}-1.981 \\
6.863 \\
259\end{array}$ & $\begin{array}{c}-4.303 \\
9.302 \\
204\end{array}$ & $\begin{array}{c}-2.695 \\
7.469 \\
726\end{array}$ & $\begin{array}{c}-2.154^{\mathrm{a}} \\
0.003\end{array}$ \\
\hline Private & Equity & $\begin{array}{c}\text { Mean } \\
\text { Std Dev } \\
n\end{array}$ & $\begin{array}{c}0.393 \\
6.244 \\
107\end{array}$ & $\begin{array}{c}2.166 \\
8.391 \\
191\end{array}$ & $\begin{array}{c}1.661 \\
9.866 \\
302\end{array}$ & $\begin{array}{c}1.596 \\
8.860 \\
600\end{array}$ & $\begin{array}{l}1.269 \\
0.214\end{array}$ \\
\hline Public & Cash & $\begin{array}{c}\text { Mean } \\
\text { Std Dev } \\
n\end{array}$ & $\begin{array}{c}-0.882 \\
4.339 \\
90\end{array}$ & $\begin{array}{c}-0.094 \\
5.026 \\
78\end{array}$ & $\begin{array}{c}0.285 \\
5.691 \\
53\end{array}$ & $\begin{array}{c}-0.324 \\
4.934 \\
221\end{array}$ & $\begin{array}{l}1.167 \\
0.170\end{array}$ \\
\hline
\end{tabular}


Table 4

Cross-sectional Regressions for Analyst Dispersion for All Equity, Public and Private Target Acquisitions OLS regressions where the dependent variable is the 3-day cumulative abnormal return measured using market model residuals. The sample of successful and unsuccessful acquisitions by publicly listed U.S. acquirers is from SDC Merger and Acquisition Database for the period 1980-2002 for all deals involving U.S. private or public targets using $100 \%$ equity payment. The sample is restricted to deals with coverage by three or more analysts and available data on long-term earnings growth forecasts. The standard deviation (std) of the long-term earnings growth forecasts are reported in percent and the yearly (quarterly) earnings forecasts are measured in dollars normalized by the stock price (stock price/4) from I/B/E/S in the month prior to the deal. Top decile long-term growth (LTG) std is equal to one if the acquirer's std is in the top decile of std among all acquirers with the same number of analysts. Leverage is measured as the ratio of long-term and short-term debt and the market value of assets (MVA). Tobin's q is defined as the book value of assets minus the book value of equity plus the market value of equity, divided by the book value of assets. Same industry deals involve targets with the same 2-digit SIC code as that of the bidder. Competed, hostile, tender offer and transaction value are from SDC. The relative transaction value (TV/MVE) represents the total value of consideration paid by the acquirer, excluding fees and expenses divided by the market value of equity. Operating cash flow is defined as sales minus the cost of goods sold, sales and general administration and working capital change, normalized by market value of assets. Small dummy is equal to one if the bidder has a market capitalization equal or less than that of the smallest quartile of NYSE firms in each year. The liquidity index for the target is calculated as the value of corporate control transactions for each year and 2-digit SIC code divided by the book value of assets of firms in the 2-digit SIC code for that year. Industry dummies are included (not reported). Respectively, ${ }^{\mathrm{a}},{ }^{\mathrm{b}}$, and ${ }^{\mathrm{c}}$ denote statistical significance at the $1 \%, 5 \%$, and $10 \%$, based on heteroscedasticity-adjusted standard errors.

\begin{tabular}{|c|c|c|c|c|}
\hline $\begin{array}{c}\text { Model } \\
\text { Target Status }\end{array}$ & $\begin{array}{c}\text { (1) } \\
\text { Public }\end{array}$ & $\begin{array}{c}\text { (2) } \\
\text { Public }\end{array}$ & $\begin{array}{c}\text { (3) } \\
\text { Private }\end{array}$ & $\begin{array}{c}\text { (4) } \\
\text { Private }\end{array}$ \\
\hline Long-term Growth (std) & $\begin{array}{c}-0.0028^{b} \\
0.024\end{array}$ & $\begin{array}{c}-0.0022^{c} \\
0.074\end{array}$ & $\begin{array}{c}-0.0007 \\
0.453\end{array}$ & $\begin{array}{c}-0.0007 \\
0.420\end{array}$ \\
\hline Leverage (MVA) & & $\begin{array}{c}0.0445^{\mathrm{b}} \\
0.034\end{array}$ & & $\begin{array}{c}-0.0547 \\
0.166\end{array}$ \\
\hline Tobin's $q$ & & $\begin{array}{c}-0.0005 \\
0.772\end{array}$ & & $\begin{array}{c}0.0001 \\
0.949\end{array}$ \\
\hline Same Industry & & $\begin{array}{c}0.0059 \\
0.340\end{array}$ & & $\begin{array}{c}-0.0262^{\mathrm{a}} \\
0.006\end{array}$ \\
\hline Tender Offer & & $\begin{array}{c}-0.0248 \\
0.301\end{array}$ & & \\
\hline Hostile Deal & & $\begin{array}{c}0.0276 \\
0.141\end{array}$ & & \\
\hline Competed Deal & & $\begin{array}{c}0.0160 \\
0.189\end{array}$ & & $\begin{array}{c}-0.0622^{\mathrm{a}} \\
0.000\end{array}$ \\
\hline $\mathrm{TV} / \mathrm{MVE}$ & & $\begin{array}{c}-0.0246^{\mathrm{a}} \\
0.006\end{array}$ & & $\begin{array}{c}0.0163 \\
0.225\end{array}$ \\
\hline Operating Cash Flow (MVA) & & $\begin{array}{c}0.0056 \\
0.130\end{array}$ & & $\begin{array}{c}0.0007 \\
0.844\end{array}$ \\
\hline Small Dummy & & $\begin{array}{c}0.0417^{\mathrm{a}} \\
0.000\end{array}$ & & $\begin{array}{c}0.0231 \\
0.191\end{array}$ \\
\hline Liquidity Index & & $\begin{array}{c}0.0207^{\mathrm{c}} \\
0.063\end{array}$ & & $\begin{array}{c}0.0017 \\
0.939\end{array}$ \\
\hline Intercept & $\begin{array}{c}-0.0551^{\mathrm{c}} \\
0.088\end{array}$ & $\begin{array}{c}-0.0127 \\
0.559\end{array}$ & $\begin{array}{c}0.0386^{\mathrm{b}} \\
0.024\end{array}$ & $\begin{array}{l}0.0258 \\
0.253\end{array}$ \\
\hline $\begin{array}{c}n \\
\text { Adjusted - } \mathrm{R}^{2}\end{array}$ & $\begin{array}{c}724 \\
0.026 \\
\end{array}$ & $\begin{array}{c}721 \\
0.072 \\
\end{array}$ & $\begin{array}{c}600 \\
0.014\end{array}$ & $\begin{array}{c}599 \\
0.026 \\
\end{array}$ \\
\hline
\end{tabular}


Table 4. (Continued)

\begin{tabular}{|c|c|c|c|c|c|}
\hline $\begin{array}{c}\text { Model } \\
\text { Target status }\end{array}$ & $\begin{array}{c}\text { (5) } \\
\text { Public }\end{array}$ & $\begin{array}{c}\text { (6) } \\
\text { Public }\end{array}$ & $\begin{array}{c}(7) \\
\text { Public }\end{array}$ & $\begin{array}{c}(8) \\
\text { Public }\end{array}$ & $\begin{array}{c}(9) \\
\text { Private }\end{array}$ \\
\hline Long-term Growth (std) & & & $\begin{array}{c}-0.0020 \\
0.121\end{array}$ & & \\
\hline Yearly Earnings (std) & $\begin{array}{c}-0.5069^{\mathrm{a}} \\
0.004\end{array}$ & & $\begin{array}{c}-0.0598 \\
0.911\end{array}$ & & \\
\hline Quarterly Earnings (std) & & $\begin{array}{c}-0.6811^{\mathrm{b}} \\
0.026\end{array}$ & $\begin{array}{c}-0.5340 \\
0.522\end{array}$ & & \\
\hline Top Decile LTG (std) & & & & $\begin{array}{c}-0.0303^{\mathrm{b}} \\
0.028\end{array}$ & $\begin{array}{c}0.0046 \\
0.696\end{array}$ \\
\hline Leverage (MVA) & $\begin{array}{c}0.0529^{\mathrm{b}} \\
0.011\end{array}$ & $\begin{array}{c}0.0517^{\mathrm{b}} \\
0.014\end{array}$ & $\begin{array}{c}0.0472^{\mathrm{b}} \\
0.031\end{array}$ & $\begin{array}{c}0.0475^{\mathrm{b}} \\
0.022\end{array}$ & $\begin{array}{c}-0.0529 \\
0.179\end{array}$ \\
\hline Tobin's $q$ & $\begin{array}{c}-0.0017 \\
0.337\end{array}$ & $\begin{array}{c}-0.0017 \\
0.339\end{array}$ & $\begin{array}{c}-0.0007 \\
0.690\end{array}$ & $\begin{array}{c}-0.0005 \\
0.797\end{array}$ & $\begin{array}{c}-0.0002 \\
0.847\end{array}$ \\
\hline Same Industry & $\begin{array}{c}0.0052 \\
0.406\end{array}$ & $\begin{array}{c}0.0053 \\
0.416\end{array}$ & $\begin{array}{c}0.0064 \\
0.322\end{array}$ & $\begin{array}{c}0.0048 \\
0.433\end{array}$ & $\begin{array}{l}-0.0257^{\mathrm{a}} \\
0.007\end{array}$ \\
\hline Tender Offer & $\begin{array}{c}-0.0259 \\
0.263\end{array}$ & $\begin{array}{c}-0.0232 \\
0.322\end{array}$ & $\begin{array}{c}-0.024 \\
0.321\end{array}$ & $\begin{array}{c}-0.0224 \\
0.357\end{array}$ & \\
\hline Hostile Deal & $\begin{array}{c}0.0314^{\mathrm{c}} \\
0.087\end{array}$ & $\begin{array}{c}0.0319^{\mathrm{c}} \\
0.080\end{array}$ & $\begin{array}{c}0.0274 \\
0.141\end{array}$ & $\begin{array}{c}0.0253 \\
0.176\end{array}$ & \\
\hline Competed Deal & $\begin{array}{c}0.0199^{\mathrm{c}} \\
0.088\end{array}$ & $\begin{array}{c}0.0214^{\mathrm{c}} \\
0.087\end{array}$ & $\begin{array}{c}0.0174 \\
0.176\end{array}$ & $\begin{array}{c}0.0150 \\
0.221\end{array}$ & $\begin{array}{l}-0.0600^{\mathrm{a}} \\
0.000\end{array}$ \\
\hline TV / MVE & $\begin{array}{c}-0.0309^{\mathrm{a}} \\
0.001\end{array}$ & $\begin{array}{c}-0.0326^{\mathrm{a}} \\
0.001\end{array}$ & $\begin{array}{c}-0.0256^{\mathrm{a}} \\
0.007\end{array}$ & $\begin{array}{c}-0.0246^{\mathrm{a}} \\
0.005\end{array}$ & $\begin{array}{c}0.0163 \\
0.225\end{array}$ \\
\hline Operating Cash Flow (MVA) & $\begin{array}{c}0.0077^{\mathrm{c}} \\
0.074\end{array}$ & $\begin{array}{c}0.0091^{\mathrm{c}} \\
0.079\end{array}$ & $\begin{array}{c}0.0063 \\
0.159\end{array}$ & $\begin{array}{c}0.0056 \\
0.143\end{array}$ & $\begin{array}{c}0.0015 \\
0.667\end{array}$ \\
\hline Small Dummy & $\begin{array}{c}0.0339^{\mathrm{a}} \\
0.005\end{array}$ & $\begin{array}{c}0.0347^{\mathrm{a}} \\
0.007\end{array}$ & $\begin{array}{c}0.0421^{\mathrm{a}} \\
0.001\end{array}$ & $\begin{array}{c}0.0401^{\mathrm{a}} \\
0.001\end{array}$ & $\begin{array}{c}0.0235 \\
0.182\end{array}$ \\
\hline Liquidity Index & $\begin{array}{c}0.0212^{\mathrm{c}} \\
0.051\end{array}$ & $\begin{array}{c}0.0216^{\mathrm{b}} \\
0.048\end{array}$ & $\begin{array}{c}0.0200^{\mathrm{c}} \\
0.073\end{array}$ & $\begin{array}{c}0.0229^{\mathrm{b}} \\
0.043\end{array}$ & $\begin{array}{c}0.0016 \\
0.944\end{array}$ \\
\hline Intercept & $\begin{array}{c}0.0390 \\
0.242\end{array}$ & $\begin{array}{c}0.0410 \\
0.229\end{array}$ & $\begin{array}{c}0.0457 \\
0.170\end{array}$ & $\begin{array}{c}-0.0254 \\
0.189\end{array}$ & $\begin{array}{c}0.0063 \\
0.768\end{array}$ \\
\hline $\begin{array}{c}n \\
\text { Adjusted - } \mathrm{R}^{2}\end{array}$ & $\begin{array}{c}739 \\
0.081\end{array}$ & $\begin{array}{c}704 \\
0.081\end{array}$ & $\begin{array}{c}691 \\
0.072\end{array}$ & $\begin{array}{c}721 \\
0.073\end{array}$ & $\begin{array}{c}599 \\
0.025\end{array}$ \\
\hline
\end{tabular}


Table 5

Abnormal Returns by Diversity of Opinion and Firm Valuation

The sample of successful and unsuccessful acquisitions by publicly listed U.S. acquirers is from SDC Merger and Acquisition Database for the period 1980-2002 for all deals involving U.S. private or public targets. The acquirer has coverage by three or more analysts and available data on long-term earnings growth forecasts. The standard deviation (std) of the long-term earnings growth forecast is from $\mathrm{I} / \mathrm{B} / \mathrm{E} / \mathrm{S}$. Tobin's $q$ is defined as the book value of assets minus the book value of equity plus the market value of equity, divided by the book value of assets. Abnormal returns are defined as the 3-day cumulative abnormal return (in percent) measured using the market model residuals, where the parameters are estimated over the $(-205,-6)$ event window relative to the announcement day. Abnormal returns are winsorized at the $1 \%$ and $99 \%$ level. Cells denote respectively the mean, standard deviation (Std Dev), and number of observations (n) for each group. The relative transaction value (TV/MVE) is from SDC and represents the total value of consideration paid by the acquirer, excluding fees and expenses divided by the market value of equity. Diagonal measures the difference between the high-high and low-low cells. Panel A is public targets with $100 \%$ equity payment, panel B is private targets with $100 \%$ equity payment, panel $\mathrm{C}$ is public targets with $100 \%$ cash payment and panel D is high valuation, high std acquisitions sorted by TV/MVE. Respectively, ${ }^{\mathrm{a}},{ }^{\mathrm{b}}$, and ${ }^{\mathrm{c}}$ denote statistical significance at the $1 \%, 5 \%$, and $10 \%$ level based on $t$-tests of the differences of the means between the high and low groups.

\begin{tabular}{|c|c|c|c|c|c|c|}
\hline \multicolumn{7}{|c|}{ Panel A: Public targets and equity consideration } \\
\hline \multirow[b]{2}{*}{ Tobin's $q$} & & \multicolumn{4}{|c|}{ Long-term growth (std) } & \multirow{2}{*}{$\begin{array}{c}\text { High - Low } \\
\text { p-value }\end{array}$} \\
\hline & & Low & Mid & High & Total & \\
\hline \multirow[t]{3}{*}{ Low } & Mean & -2.010 & -2.028 & -2.268 & -2.042 & -0.257 \\
\hline & Std Dev & 4.885 & 5.540 & 8.084 & 5.474 & 0.822 \\
\hline & $n$ & 153 & 92 & 27 & 272 & \\
\hline \multirow[t]{3}{*}{ Mid } & Mean & -1.536 & -1.352 & -1.569 & -1.477 & -0.033 \\
\hline & Std Dev & 6.552 & 7.470 & 9.316 & 7.790 & 0.984 \\
\hline & $n$ & 50 & 60 & 50 & 160 & \\
\hline \multirow[t]{6}{*}{ High } & Mean & -3.016 & -2.294 & -5.812 & -3.961 & $-2.797^{b}$ \\
\hline & Std Dev & 8.434 & 7.544 & 9.275 & 8.636 & 0.049 \\
\hline & $n$ & 60 & 107 & 127 & 294 & \\
\hline & & & & & & $\begin{array}{c}\text { Diagonal } \\
\text { p-value }\end{array}$ \\
\hline & High - Low & -1.005 & -0.266 & $-3.545^{\mathrm{c}}$ & $-1.919^{a}$ & $-3.802^{\mathrm{a}}$ \\
\hline & p-value & 0.280 & 0.781 & 0.068 & 0.002 & 0.000 \\
\hline \multicolumn{7}{|c|}{ Panel B: Private targets and equity consideration } \\
\hline \multirow{2}{*}{\multicolumn{2}{|c|}{ Tobin's $q$}} & & ong-term & owth (stc & & High - Low \\
\hline & & Low & Mid & High & Total & -value \\
\hline \multirow[t]{3}{*}{ Low } & Mean & -1.138 & 5.029 & -0.144 & 1.651 & 0.995 \\
\hline & Std Dev & 3.127 & 12.617 & 6.103 & 9.166 & 0.559 \\
\hline & $n$ & 17 & 22 & 15 & 54 & \\
\hline \multirow[t]{3}{*}{ Mid } & Mean & -0.595 & 3.784 & -0.052 & 1.433 & 0.543 \\
\hline & Std Dev & 5.154 & 8.900 & 8.353 & 8.227 & 0.761 \\
\hline & $n$ & 27 & 53 & 47 & 127 & \\
\hline \multirow[t]{6}{*}{ High } & Mean & 1.229 & 0.883 & 2.110 & 1.638 & 0.881 \\
\hline & Std Dev & 7.156 & 6.856 & 10.295 & 9.024 & 0.523 \\
\hline & $n$ & 63 & 116 & 240 & 419 & \\
\hline & & & & & & $\begin{array}{c}\text { Diagonal } \\
p \text {-value }\end{array}$ \\
\hline & High-Low & 2.367 & $-4.146^{\mathrm{b}}$ & 2.254 & -0.013 & 3.248 \\
\hline & (p-value) & 0.189 & 0.028 & 0.403 & 0.992 & 0.197 \\
\hline
\end{tabular}


Table 5. (Continued)

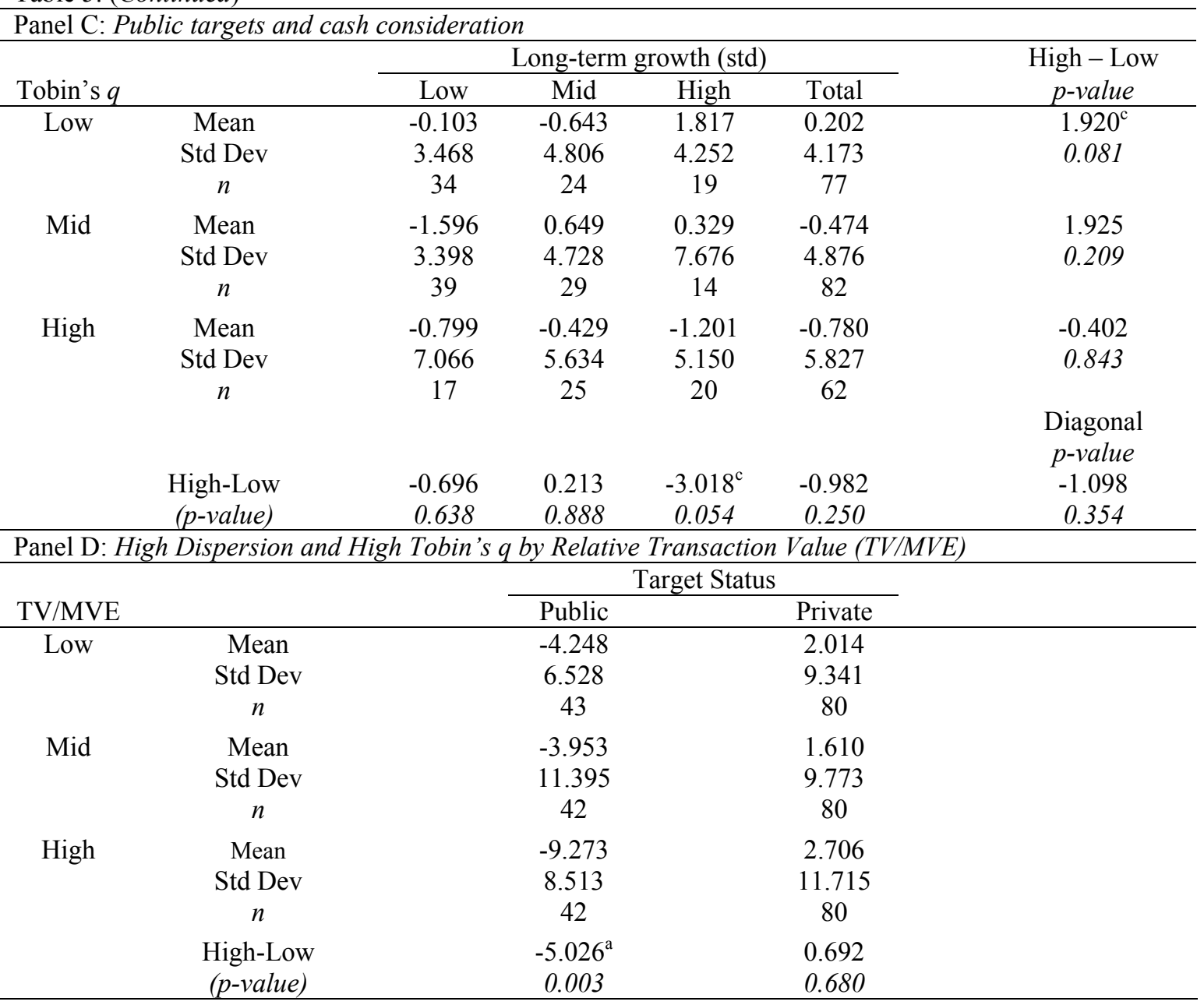


Table 6

Cross-sectional Regression with Information Asymmetry Measures for Public Acquisitions

OLS regressions where the dependent variable is the 3-day cumulative abnormal return measured using market model residuals. The sample of successful and unsuccessful acquisitions by publicly listed U.S. acquirers is from SDC Merger and Acquisition Database for the period 1980-2002 for all deals involving U.S. public targets using either $100 \%$ equity payment or $100 \%$ cash payment. The sample is restricted to deals with coverage by three or more analysts and available data on long-term earnings growth forecasts. The standard deviation (std) of the long-term earnings growth forecasts are reported in percent. Top decile longterm growth (LTG) is equal to one if the acquirer's std is in the top decile of std among all acquirers with the same number of analysts. Volatility is measured as the standard deviation of the market-adjusted residuals of the daily stock returns measured during the period starting from 205 days to 6 days prior to the acquisition announcement. In models (2), (3), (6) and (7) volatility is orthogonal to the standard deviation of long-term growth. The earnings announcement standard deviation (std) is measured as the standard deviation of all 3day cumulative abnormal returns around earnings announcements from $\mathrm{I} / \mathrm{B} / \mathrm{E} / \mathrm{S}$ using the market model over the 5 year period preceding the acquisition announcement. Turnover is defined as the median of daily volume divided by shares outstanding from day $(-205,-6)$ relative to the acquisition announcement day. Leverage is measured as the ratio of long-term and short-term debt and the market value of assets (MVA). Tobin's $q$ is defined as the book value of assets minus the book value of equity plus the market value of equity, divided by the book value of assets. Same industry deals involve targets with the same 2-digit SIC code as that of the bidder. Competed, hostile, tender offer and transaction value are from SDC. The relative transaction value (TV/MVE) represents the total value of consideration paid by the acquirer, excluding fees and expenses divided by the market value of equity. Operating cash flow is defined as sales minus the cost of goods sold, sales and general administration and working capital change, normalized by market value of assets. Small dummy is equal to one if the bidder has a market capitalization equal or less than that of the smallest quartile of NYSE firms in each year. The liquidity index for the target is calculated as the value of corporate control transactions for each year and 2-digit SIC code divided by the book value of assets of firms in the 2-digit SIC code for that year. Industry dummies are included (not reported). Respectively, ${ }^{\mathrm{a}},{ }^{\mathrm{b}}$, and ${ }^{\mathrm{c}}$ denote statistical significance at the $1 \%, 5 \%$, and $10 \%$, based on heteroscedasticity-adjusted standard errors.

\begin{tabular}{|c|c|c|c|c|c|c|c|c|}
\hline $\begin{array}{c}\text { Model } \\
\text { Payment }\end{array}$ & $\begin{array}{c}\text { (1) } \\
\text { Equity }\end{array}$ & $\begin{array}{c}\text { (2) } \\
\text { Equity }\end{array}$ & $\begin{array}{c}\text { (3) } \\
\text { Equity }\end{array}$ & $\begin{array}{c}\text { (4) } \\
\text { Equity }\end{array}$ & $\begin{array}{c}\text { (5) } \\
\text { Cash }\end{array}$ & $\begin{array}{c}6) \\
\text { Cash }\end{array}$ & $\begin{array}{c}(7) \\
\text { Cash }\end{array}$ & $\begin{array}{c}(8) \\
\text { Cash }\end{array}$ \\
\hline $\begin{array}{l}\text { Long-term } \\
\text { Growth (std) }\end{array}$ & $\begin{array}{c}-0.0005 \\
0.741\end{array}$ & $\begin{array}{c}-0.0020 \\
0.130\end{array}$ & & $\begin{array}{c}-0.0002 \\
0.893\end{array}$ & $\begin{array}{c}0.0018 \\
0.186\end{array}$ & $\begin{array}{c}0.0030^{\mathrm{b}} \\
0.022\end{array}$ & & $\begin{array}{c}0.0013 \\
0.463\end{array}$ \\
\hline $\begin{array}{l}\text { Top Decile LTG } \\
\text { (std) }\end{array}$ & & & $\begin{array}{c}-0.0332^{b} \\
0.025\end{array}$ & & & & $\begin{array}{r}0.0363^{b} \\
0.026\end{array}$ & \\
\hline Volatility & $\begin{array}{c}-0.9778^{\mathrm{a}} \\
0.009\end{array}$ & & & $\begin{array}{c}-0.8818^{\mathrm{c}} \\
0.073\end{array}$ & $\begin{array}{r}0.8078^{\mathrm{b}} \\
0.037\end{array}$ & & & $\begin{array}{c}0.8264 \\
0.105\end{array}$ \\
\hline $\begin{array}{c}\text { Volatility } \\
\text { Orthogonalized }\end{array}$ & & $\begin{array}{c}-0.9778^{\mathrm{a}} \\
0.009\end{array}$ & $\begin{array}{c}-0.9750^{\mathrm{a}} \\
0.008\end{array}$ & & & $\begin{array}{c}0.8078^{\mathrm{b}} \\
0.037\end{array}$ & $\begin{array}{r}0.7949^{\mathrm{b}} \\
0.044\end{array}$ & \\
\hline $\begin{array}{c}\text { Earnings } \\
\text { Announcement } \\
\text { Residual (std) }\end{array}$ & & & & $\begin{array}{c}-0.0908 \\
0.469\end{array}$ & & & $\begin{array}{c}-0.1741 \\
0.332\end{array}$ & \\
\hline Turnover & & & & $\begin{array}{c}-0.0001 \\
0.920\end{array}$ & & & & $\begin{array}{c}0.0011 \\
0.539\end{array}$ \\
\hline Leverage (MVA) & $\begin{array}{c}0.0321 \\
0.167\end{array}$ & $\begin{array}{c}0.0321 \\
0.167\end{array}$ & $\begin{array}{c}0.0348 \\
0.127\end{array}$ & $\begin{array}{c}0.0288 \\
0.216\end{array}$ & $\begin{array}{c}0.0019 \\
0.934\end{array}$ & $\begin{array}{c}0.0019 \\
0.934\end{array}$ & $\begin{array}{l}-0.0029 \\
0.905\end{array}$ & $\begin{array}{c}-0.0039 \\
0.881\end{array}$ \\
\hline Tobin's $q$ & $\begin{array}{c}0.0002 \\
0.919\end{array}$ & $\begin{array}{c}0.0002 \\
0.919\end{array}$ & $\begin{array}{c}0.0005 \\
0.828\end{array}$ & $\begin{array}{c}0.0005 \\
0.830\end{array}$ & $\begin{array}{c}-0.0045 \\
0.289\end{array}$ & $\begin{array}{c}-0.0045 \\
0.289\end{array}$ & $\begin{array}{c}-0.0060 \\
0.219\end{array}$ & $\begin{array}{c}-0.0050 \\
0.283\end{array}$ \\
\hline
\end{tabular}


Table 6. (Continued)

\begin{tabular}{ccccccccc}
\hline Model & $(1)$ & $(2)$ & $(3)$ & $(4)$ & $(5)$ & $(6)$ & $(7)$ & $(8)$ \\
Payment & Equity & Equity & Equity & Equity & Cash & Cash & Cash & Cash \\
\hline Same Industry & 0.0076 & 0.0076 & 0.0066 & 0.0074 & -0.0037 & -0.0037 & -0.0037 & -0.0084 \\
& 0.224 & 0.224 & 0.286 & 0.237 & 0.655 & 0.655 & 0.655 & 0.301 \\
Tender Offer & -0.0240 & -0.0240 & -0.0201 & -0.0297 & 0.0092 & 0.0092 & 0.0100 & 0.0119 \\
& 0.324 & 0.324 & 0.411 & 0.224 & 0.231 & 0.231 & 0.189 & 0.127 \\
Hostile Deal & 0.0259 & 0.0259 & 0.0229 & 0.0287 & -0.0098 & -0.0098 & -0.0109 & $-0.0183^{\mathrm{c}}$ \\
& 0.158 & 0.158 & 0.212 & 0.117 & 0.418 & 0.418 & 0.356 & 0.100 \\
Competed Deal & 0.0169 & 0.0169 & 0.0154 & 0.0156 & -0.0147 & -0.0147 & -0.0142 & -0.0015 \\
& 0.178 & 0.178 & 0.220 & 0.213 & 0.261 & 0.261 & 0.280 & 0.868 \\
TV / MVE & $-0.0265^{\mathrm{a}}$ & $-0.0265^{\mathrm{a}}$ & $-0.0262^{\mathrm{a}}$ & $-0.0252^{\mathrm{a}}$ & 0.0099 & 0.0099 & 0.0100 & $0.0216^{\mathrm{a}}$ \\
& 0.002 & 0.002 & 0.002 & 0.006 & 0.384 & 0.384 & 0.401 & 0.001 \\
Operating Cash & & & & & & & $-0.0274^{\mathrm{b}}$ & $-0.0255^{\mathrm{c}}$ \\
Flow (MVA) & 0.0023 & 0.0023 & 0.0024 & 0.0013 & $-0.0268^{\mathrm{b}}$ & $-0.0268^{\mathrm{b}}$ & -0.029 & 0.060 \\
& 0.488 & 0.488 & 0.503 & 0.778 & 0.032 & 0.032 & 0.029 & 0.060 \\
Small Dummy & $0.0545^{\mathrm{a}}$ & $0.0545^{\mathrm{a}}$ & $0.0530^{\mathrm{a}}$ & $0.0548^{\mathrm{a}}$ & $-0.0280^{\mathrm{c}}$ & $-0.0280^{\mathrm{c}}$ & $-0.0294^{\mathrm{c}}$ & $-0.0585^{\mathrm{a}}$ \\
& 0.000 & 0.000 & 0.000 & 0.001 & 0.081 & 0.081 & 0.080 & 0.000 \\
Liquidity Index & 0.0137 & 0.0137 & 0.0157 & -0.0004 & $-0.0370^{\mathrm{b}}$ & $-0.0370^{\mathrm{b}}$ & $-0.0366^{\mathrm{b}}$ & $-0.0400^{\mathrm{b}}$ \\
& 0.184 & 0.184 & 0.129 & 0.431 & 0.027 & 0.027 & 0.034 & 0.020 \\
Intercept & 0.0566 & 0.0352 & 0.0251 & 0.0124 & $-0.0490^{\mathrm{c}}$ & $-0.0313^{\mathrm{c}}$ & -0.0131 & $-0.0435^{\mathrm{b}}$ \\
& 0.154 & 0.368 & 0.526 & 0.591 & 0.009 & 0.074 & 0.462 & 0.043 \\
Adjusted - R ${ }^{2}$ & 6.079 & 0.079 & 0.083 & 0.071 & 0.057 & 0.057 & 0.056 & 0.079 \\
\hline
\end{tabular}


Table 7

Cross-sectional Regression for Forecast Revisions for 100\% Equity, Public and Private Target Acquisitions OLS regressions where the dependent variable is the 3-day cumulative abnormal return measured using market model residuals. The sample of successful and unsuccessful acquisitions by publicly listed U.S. acquirers is from SDC Merger and Acquisition Database for the period 1980-2002 for all deals involving U.S. private or public targets using $100 \%$ equity payment. The sample is restricted to deals with coverage by three or more analysts and available data on long-term earnings growth forecasts. The standard deviation (std) of the long-term earnings growth forecasts are reported in percent. Top decile long-term growth (std) is equal to one if the acquirer's std is in the top decile of std among all acquirers with the same number of analysts. Forecast revisions of the long-term growth forecasts for the std and median are the changes from the month before the announcement to the month after the announcement. Leverage is measured as the ratio of long-term and short-term debt and the market value of assets (MVA). Tobin's $q$ is defined as the book value of assets minus the book value of equity plus the market value of equity, divided by the book value of assets. Same industry deals involve targets with the same 2-digit SIC code as that of the bidder. Competed, hostile, tender offer and transaction value are from SDC. The relative transaction value (TV/MVE) represents the total value of consideration paid by the acquirer, excluding fees and expenses divided by the market value of equity. Operating cash flow is defined as sales minus the cost of goods sold, sales and general administration and working capital change, normalized by market value of assets. Small dummy is equal to one if the bidder has a market capitalization equal or less than that of the smallest quartile of NYSE firms in each year. The liquidity index for the target is calculated as the value of corporate control transactions for each year and 2-digit SIC code divided by the book value of assets of firms in the 2-digit SIC code for that year. Industry dummies are included (not reported). Respectively, ${ }^{a},{ }^{b}$, and ${ }^{\mathrm{c}}$ denote statistical significance at the $1 \%, 5 \%$, and $10 \%$, based on heteroscedasticity-adjusted standard errors.

\begin{tabular}{|c|c|c|c|c|c|c|c|c|}
\hline $\begin{array}{c}\text { Model } \\
\text { Target status }\end{array}$ & $\begin{array}{c}(1) \\
\text { Public }\end{array}$ & $\begin{array}{c}(2) \\
\text { Private }\end{array}$ & $\begin{array}{c}\text { (3) } \\
\text { Public }\end{array}$ & $\begin{array}{c}\text { (4) } \\
\text { Private }\end{array}$ & $\begin{array}{c}\text { (5) } \\
\text { Public }\end{array}$ & $\begin{array}{c}\text { (6) } \\
\text { Private }\end{array}$ & $\begin{array}{c}\text { (7) } \\
\text { Public }\end{array}$ & $\begin{array}{c}(8) \\
\text { Private }\end{array}$ \\
\hline $\begin{array}{l}\text { Long-term } \\
\text { Growth (std) }\end{array}$ & $\begin{array}{c}-0.0024^{\mathrm{b}} \\
0.044\end{array}$ & $\begin{array}{l}-0.0003 \\
0.743\end{array}$ & $\begin{array}{c}-0.0017 \\
0.152\end{array}$ & $\begin{array}{c}-0.0007 \\
0.509\end{array}$ & & & & \\
\hline $\begin{array}{l}\text { Top Decile LTG } \\
\text { (std) }\end{array}$ & & & & & $\begin{array}{c}-0.0334^{\mathrm{b}} \\
0.016\end{array}$ & $\begin{array}{c}0.0071 \\
0.570\end{array}$ & $\begin{array}{c}-0.0244^{\mathrm{c}} \\
0.073\end{array}$ & $\begin{array}{c}0.0058 \\
0.641\end{array}$ \\
\hline $\begin{array}{c}\text { Forecast Revision } \\
\text { LTG (std) }\end{array}$ & $\begin{array}{c}0.0046 \\
0.151\end{array}$ & $\begin{array}{c}0.0009 \\
0.788\end{array}$ & $\begin{array}{c}0.0061^{\mathrm{b}} \\
0.048\end{array}$ & $\begin{array}{c}0.0009 \\
0.788\end{array}$ & $\begin{array}{c}0.0048 \\
0.140\end{array}$ & $\begin{array}{c}0.0015 \\
0.645\end{array}$ & $\begin{array}{c}0.0062^{\mathrm{b}} \\
0.046\end{array}$ & $\begin{array}{c}0.0008 \\
0.446\end{array}$ \\
\hline $\begin{array}{c}\text { Forecast Revision } \\
\text { LTG (median) }\end{array}$ & $\begin{array}{c}0.0025 \\
0.203\end{array}$ & $\begin{array}{c}-0.0001 \\
0.820\end{array}$ & $\begin{array}{c}0.0021 \\
0.290\end{array}$ & $\begin{array}{c}0.0000 \\
0.956\end{array}$ & $\begin{array}{c}0.0026 \\
0.218\end{array}$ & $\begin{array}{c}-0.0002 \\
0.679\end{array}$ & $\begin{array}{c}0.0021 \\
0.295\end{array}$ & $\begin{array}{c}-0.0002 \\
0.783\end{array}$ \\
\hline Leverage (MVA) & & & $\begin{array}{c}0.0410^{\mathrm{c}} \\
0.066\end{array}$ & $\begin{array}{c}-0.0498 \\
0.200\end{array}$ & & & $\begin{array}{c}0.0435^{\mathrm{b}} \\
0.047\end{array}$ & $\begin{array}{c}-0.0471 \\
0.226\end{array}$ \\
\hline Tobin's $q$ & & & $\begin{array}{c}-0.0008 \\
0.666\end{array}$ & $\begin{array}{c}0.0004 \\
0.758\end{array}$ & & & $\begin{array}{c}-0.0007 \\
0.700\end{array}$ & $\begin{array}{c}0.0000 \\
0.979\end{array}$ \\
\hline Same Industry & & & $\begin{array}{c}0.0049 \\
0.427\end{array}$ & $\begin{array}{l}-0.0278^{\mathrm{a}} \\
0.006\end{array}$ & & & $\begin{array}{c}0.0040 \\
0.517\end{array}$ & $\begin{array}{c}-0.0272^{\mathrm{a}} \\
0.007\end{array}$ \\
\hline Tender Offer & & & $\begin{array}{c}-0.0223 \\
0.331\end{array}$ & & & & $\begin{array}{c}-0.0202 \\
0.382\end{array}$ & \\
\hline Hostile Deal & & & $\begin{array}{c}0.0274 \\
0.160\end{array}$ & & & & $\begin{array}{c}0.0254 \\
0.194\end{array}$ & \\
\hline Competed Deal & & & $\begin{array}{c}0.0151 \\
0.222\end{array}$ & $\begin{array}{l}-0.0660^{\mathrm{a}} \\
0.000\end{array}$ & & & $\begin{array}{c}0.0142 \\
0.249\end{array}$ & $\begin{array}{c}-0.0631^{\mathrm{a}} \\
0.000\end{array}$ \\
\hline TV / MVE & & & $\begin{array}{c}-0.0252^{\mathrm{a}} \\
0.009 \\
\end{array}$ & $\begin{array}{c}0.0746^{\mathrm{b}} \\
0.011 \\
\end{array}$ & & & $\begin{array}{c}-0.0252^{\mathrm{a}} \\
0.008 \\
\end{array}$ & $\begin{array}{c}0.0731^{\mathrm{b}} \\
0.011 \\
\end{array}$ \\
\hline
\end{tabular}


Table 7. (Continued)

\begin{tabular}{|c|c|c|c|c|c|c|c|c|}
\hline $\begin{array}{c}\text { Model } \\
\text { Target status }\end{array}$ & $\begin{array}{c}\text { (1) } \\
\text { Public }\end{array}$ & $\begin{array}{c}(2) \\
\text { Private }\end{array}$ & $\begin{array}{c}(3) \\
\text { Public }\end{array}$ & $\begin{array}{c}(4) \\
\text { Private }\end{array}$ & $\begin{array}{c}(5) \\
\text { Public }\end{array}$ & $\begin{array}{c}(6) \\
\text { Private }\end{array}$ & $\begin{array}{c}(7) \\
\text { Public }\end{array}$ & $\begin{array}{c}(8) \\
\text { Private }\end{array}$ \\
\hline $\begin{array}{c}\text { Operating Cash } \\
\text { Flow (MVA) }\end{array}$ & & & $\begin{array}{c}0.0066 \\
0.222\end{array}$ & $\begin{array}{c}0.0005 \\
0.898\end{array}$ & & & $\begin{array}{c}0.0068 \\
0.222\end{array}$ & $\begin{array}{c}0.0013 \\
0.704\end{array}$ \\
\hline Small Dummy & & & $\begin{array}{c}0.0490^{\mathrm{a}} \\
0.001\end{array}$ & $\begin{array}{c}0.0194 \\
0.308\end{array}$ & & & $\begin{array}{c}0.0474^{\mathrm{a}} \\
0.001\end{array}$ & $\begin{array}{c}0.0204 \\
0.290\end{array}$ \\
\hline Liquidity Index & & & $\begin{array}{c}0.0194^{\mathrm{c}} \\
0.077^{-}\end{array}$ & $\begin{array}{c}-0.0044 \\
0.834\end{array}$ & & & $\begin{array}{c}0.0212^{\mathrm{c}} \\
0.056\end{array}$ & $\begin{array}{c}-0.0053 \\
0.802\end{array}$ \\
\hline Intercept & $\begin{array}{c}0.0579^{c} \\
0.076\end{array}$ & $\begin{array}{c}0.0368^{\mathrm{c}} \\
0.068\end{array}$ & $\begin{array}{c}-0.0173 \\
0.471\end{array}$ & $\begin{array}{c}0.0127 \\
0.609\end{array}$ & $\begin{array}{c}0.0487 \\
0.143\end{array}$ & $\begin{array}{c}0.0267 \\
0.131\end{array}$ & $\begin{array}{c}-0.0288 \\
0.165\end{array}$ & $\begin{array}{c}-0.0071 \\
0.765\end{array}$ \\
\hline $\begin{array}{c}n \\
\text { Adjusted - } \mathrm{R}^{2}\end{array}$ & $\begin{array}{c}711 \\
0.037\end{array}$ & $\begin{array}{c}574 \\
-0.001\end{array}$ & $\begin{array}{c}708 \\
0.082\end{array}$ & $\begin{array}{c}573 \\
0.026\end{array}$ & $\begin{array}{c}711 \\
0.038\end{array}$ & $\begin{array}{c}574 \\
-0.001\end{array}$ & $\begin{array}{c}708 \\
0.083\end{array}$ & $\begin{array}{c}573 \\
0.025\end{array}$ \\
\hline
\end{tabular}


Table 8

Post-Announcement Abnormal returns by Diversity of Opinion and Firm Valuation

The sample of successful and unsuccessful acquisitions by publicly listed U.S. acquirers is from SDC Merger and Acquisition Database for the period 1980-2002 for all deals involving U.S. private or public targets. The acquirer has coverage by three or more analysts and available data on long-term earnings growth forecasts. The standard deviation (std) of the long-term earnings growth forecast is from $\mathrm{I} / \mathrm{B} / \mathrm{E} / \mathrm{S}$. Tobin's $q$ is defined as the book value of assets minus the book value of equity plus the market value of equity, divided by the book value of assets. Post-Announcement Abnormal returns are defined as the cumulative abnormal return (in percent) over the 20 trading days subsequent to the announcement period, starting at day +2 , measured using the market model residuals. Cells denote respectively the mean, standard deviation (Std Dev), and number of observations $(n)$ for each group. Diagonal measures the difference between the high-high and low-low cells. Respectively, ${ }^{\mathrm{a}},{ }^{\mathrm{b}}$, and ${ }^{\mathrm{c}}$ denote statistical significance at the $1 \%$, $5 \%$, and $10 \%$ level based on $t$-tests of the differences of the means between the high and low groups.

\begin{tabular}{|c|c|c|c|c|c|c|}
\hline \multicolumn{7}{|c|}{ Panel A: Public targets and equity consideration } \\
\hline \multirow[b]{2}{*}{ Tobin's $q$} & & \multicolumn{4}{|c|}{ Long-term growth (std) } & \multirow{2}{*}{$\begin{array}{c}\text { High - Low } \\
\text { p-value }\end{array}$} \\
\hline & & Low & Mid & High & Total & \\
\hline \multirow[t]{3}{*}{ Low } & Mean & -1.380 & -2.504 & -2.451 & -1.866 & -1.071 \\
\hline & Std Dev & 7.179 & 9.157 & 18.887 & 9.461 & 0.615 \\
\hline & $n$ & 147 & 90 & 24 & 261 & \\
\hline \multirow[t]{3}{*}{ Mid } & Mean & -1.444 & 1.734 & -3.717 & -0.866 & -2.273 \\
\hline & Std Dev & 9.688 & 10.912 & 17.858 & 13.143 & 0.444 \\
\hline & $n$ & 48 & 60 & 45 & 153 & \\
\hline \multirow[t]{3}{*}{ High } & Mean & 0.211 & 0.053 & -5.694 & -2.285 & $-5.905^{\mathrm{b}}$ \\
\hline & Std Dev & 12.913 & 13.610 & 18.329 & 15.815 & 0.031 \\
\hline & $n$ & 57 & 104 & 113 & 274 & \\
\hline \multirow[t]{6}{*}{ Total } & Mean & -1.032 & -0.456 & -4.778 & -1.810 & $-3.746^{\mathrm{a}}$ \\
\hline & Std Dev & 9.231 & 11.637 & 18.228 & 13.106 & 0.005 \\
\hline & $n$ & 252 & 254 & 182 & 688 & \\
\hline & & & & & & $\begin{array}{c}\text { Diagonal } \\
p \text {-value }\end{array}$ \\
\hline & High - Low & 1.591 & 2.556 & -3.243 & -0.419 & $-4.315^{\mathrm{a}}$ \\
\hline & p-value & 0.266 & 0.133 & 0.435 & 0.712 & 0.010 \\
\hline \multicolumn{7}{|c|}{ Panel B: Private targets and equity consideration } \\
\hline \multirow{2}{*}{\multicolumn{2}{|c|}{ Tobin's $q$}} & \multicolumn{4}{|c|}{ Long-term growth (std) } & High - Low \\
\hline & & Low & Mid & High & Total & p-value \\
\hline \multirow[t]{3}{*}{ Low } & Mean & 1.165 & 6.112 & -5.161 & 1.459 & -6.326 \\
\hline & Std Dev & 8.037 & 22.049 & 14.745 & 16.950 & 0.140 \\
\hline & $n$ & 17 & 21 & 14 & 52 & \\
\hline \multirow[t]{3}{*}{ Mid } & Mean & -2.704 & -3.505 & -3.724 & -3.423 & -1.020 \\
\hline & Std Dev & 9.668 & 12.729 & 17.638 & 14.241 & 0.798 \\
\hline & $n$ & 23 & 44 & 43 & 110 & \\
\hline \multirow[t]{3}{*}{ High } & Mean & -3.225 & 0.278 & -3.438 & -2.405 & -0.213 \\
\hline & Std Dev & 17.709 & 15.914 & 21.700 & 19.736 & 0.945 \\
\hline & $n$ & 59 & 105 & 226 & 390 & \\
\hline \multirow[t]{6}{*}{ Total } & Mean & -2.350 & 0.019 & -3.566 & -2.244 & -1.216 \\
\hline & Std Dev & 14.825 & 16.202 & 20.790 & 18.528 & 0.592 \\
\hline & $n$ & 99 & 170 & 283 & 552 & \\
\hline & & & & & & $\begin{array}{c}\text { Diagonal } \\
\text { p-value }\end{array}$ \\
\hline & High-Low & -4.390 & -5.834 & 1.723 & -3.865 & -4.602 \\
\hline & (p-value) & 0.326 & 0.155 & 0.770 & 0.179 & 0.386 \\
\hline
\end{tabular}

